\title{
برنامج مقترح قائم على لعب الأدوار فى تنمية مهارات المبادرة التفاعلية لدى أطفال الروضية
}

$$
\text { إعراد }
$$

الباحثة/ رشا فؤاد توفيق عبد العزيز

$$
\begin{aligned}
& \text { إشراف } \\
& \text { د د اعبير عبـده الشـرقاوي } \\
& \text { مدرس علم النفس الطفل } \\
& \text { كليتت التربيت للطفولت المبكرة } \\
& \text { جامعت المنصورة } \\
& \text { أ.د / أمل محمد القداح } \\
& \text { أستاذ مناهـج وبرامـج الطفل } \\
& \text { وكيل الدراسات العليا والبحوث }
\end{aligned}
$$

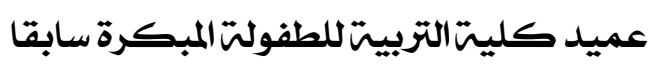

$$
\begin{aligned}
& \text { جامعت المنصورة }
\end{aligned}
$$

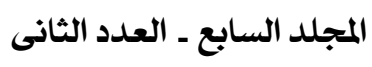

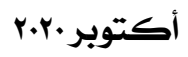

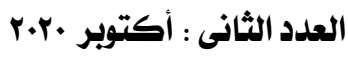




\section{برنامج مقترح قائم على لعب الأدوار فى تنمية مهارات المبادرة

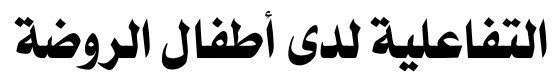

رشا فؤاد توفيق عبد العزيز *

\section{مقدمة البحث}

تسعى الدول و المجتمعات إلى تحسين مستوى التعليم لأبنائها ، مسـتخدمة

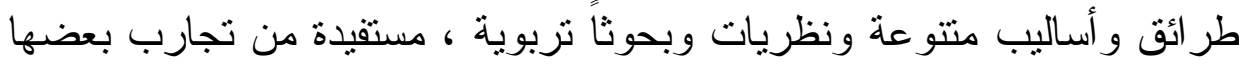

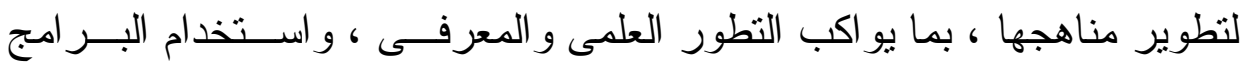

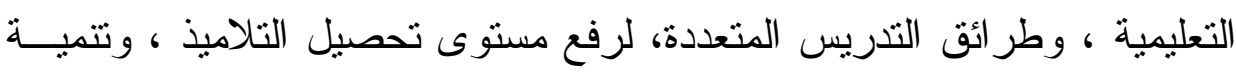

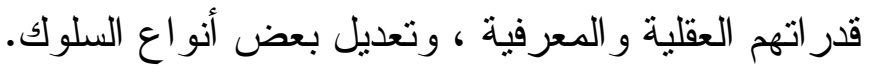

ومن هذه الطر ائق و الاستر اتيجيات ، طريقة لعــب الأدو ار التـى تتــيح

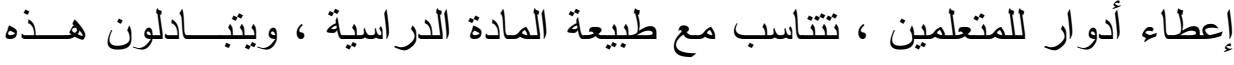

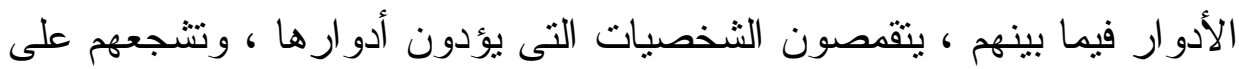
الجر أة و الطلاقة فى التعبير ، وتساعد فى حل الكثير من الاضطر ابات الــسلوكية

، وتتمية قدرتهم على طرح الأسئلة ، وتقييم العمل فى نهاية الموقف التعليهـى ،

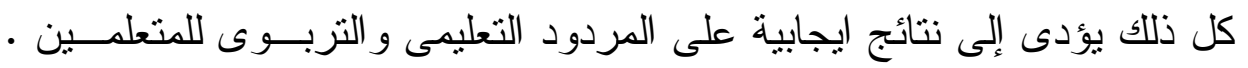

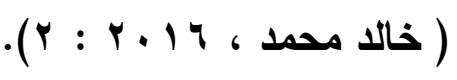

ويطلق أحياناً على لعب الأدوار اللعب التمثيلى ، حيث يقوم الطفل بتمثيل

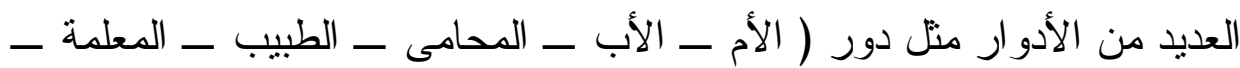

* باحثتماجستير

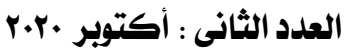


الضابط ...... الخ) ويتم ذللك داخل حجرة الدر اسة وبملابس الروضة بـصورة

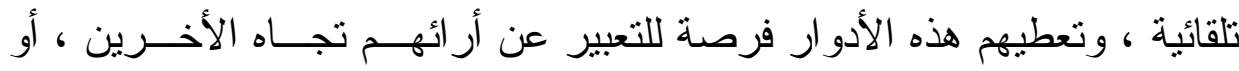

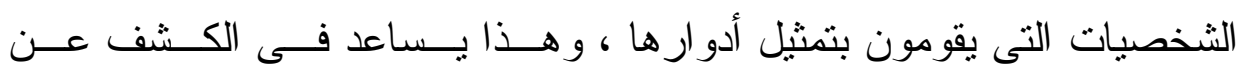
مشاعر هم ودو افعهم و انفعالاتهم ، من خلال تقمصهم للشخصيات التى يقومــون

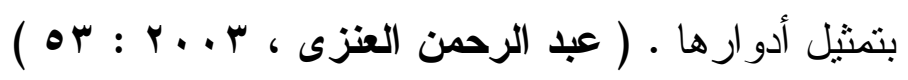

وتعتبر مرحلة الطفولة هى بحق الأساس لنخصية الإنسـسان وحياتـهـ ،

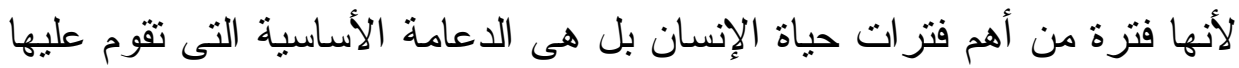

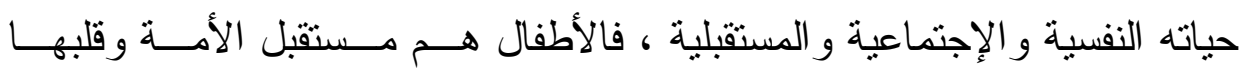

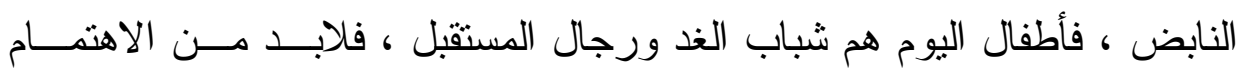

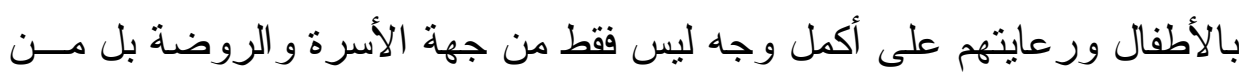

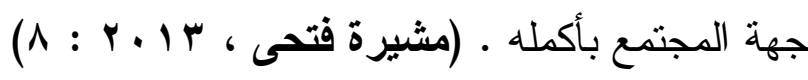

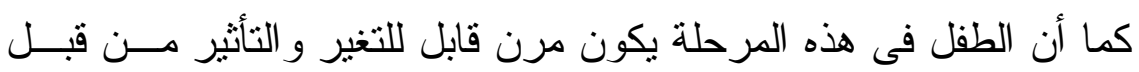

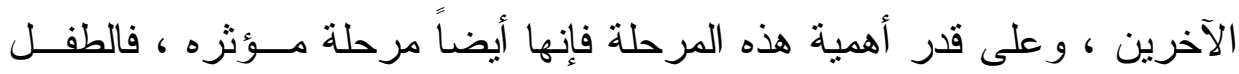

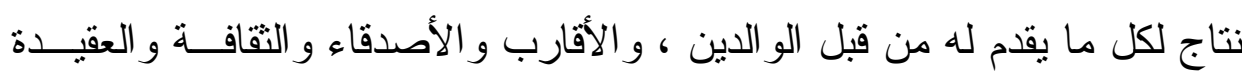

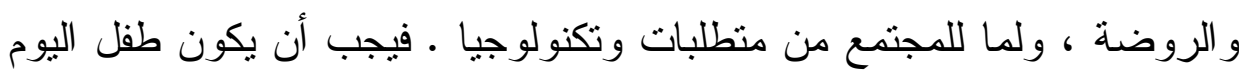

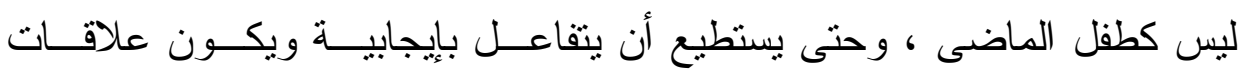

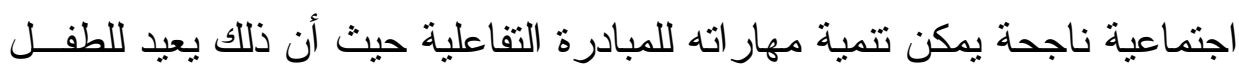

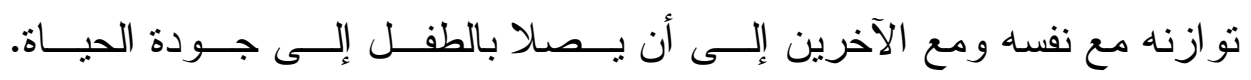

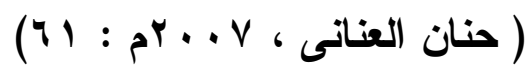

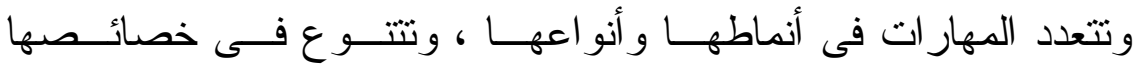

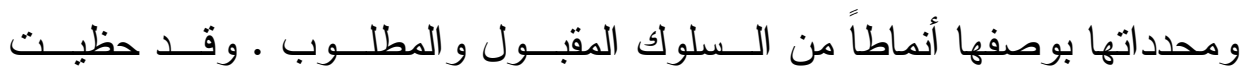


المهار ات ذات الصلة بالآخرين منها باهتمام خاص. وتتمتل فـى أنمــاط مـن المهار ات تتضمن أساليب حسن التصرف فى المو اقف عند التعامل مع الآخــرين

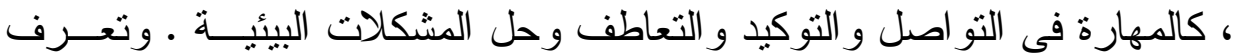
متل هذه المهارات بـ " المهار ات الاجتماعية " ، ويطلق عليها بعض المشتغلين

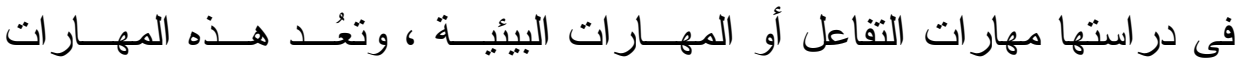

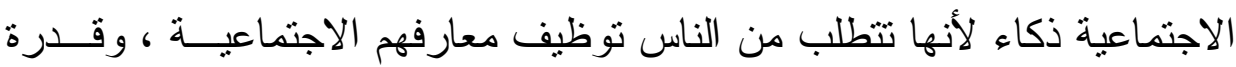

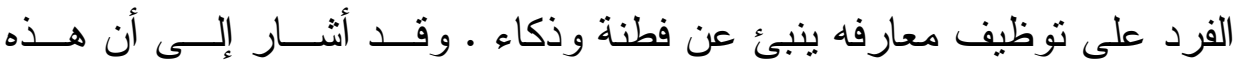

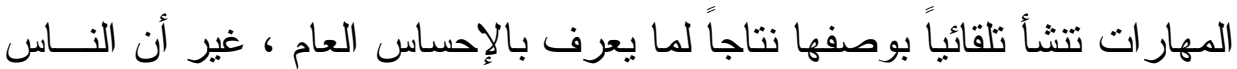
ليسو او اعين بالمسائل الصغيرة اللازمة لارتباطهم بالآخرين • ومسن ثـم كــان

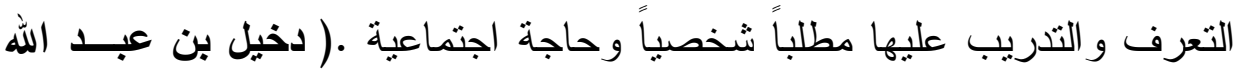

$(V: r+1 \varepsilon \sigma$

مشكلة البحث

تتحدد مشكلة البحث الحالى فى قصور وضعف تتمية مهار ات المبادرة

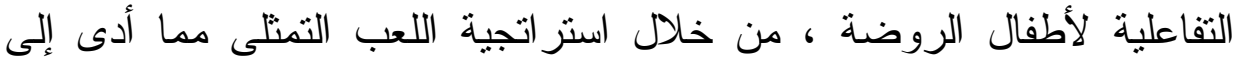
وجود اتجاهات سلوكية سلبية نحو تعلم هذه المهار ات لدى طفل الروضة ومن لإني هذه المشكلة حاول البحث الحالى الإجابة على التساؤل الرئيسى الأتى : ما فاعلية برنامج مقترح قائم على اللعب التمثيلى في تنمية مهارات المبادرة التفاعلية لاى طقل الروضة ؟ ويتفرع من هذا التساؤل الرئيسى التساؤلات الفرعية التالية : 1-ما مهارات المبادرة التفاعلية المناسبة لطفل الروضة التى يسعى

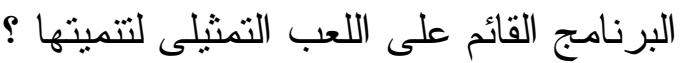


r-ما إمكانية تتمية مهار ات المبادرة التفاعلية لدى طفل الروضة باستخدام

$$
\text { اللعب التمثيلى ؟ التب }
$$

ب-ما البرنامج المقترح القائم على اللعب التمثيلى لتتمية بعض مهار ات

المبادرة التفاعلية لدى طفل الروضة ؟

ع-ما فاعلية استخدام البرنامج المقترح القائم على اللعب التمثيلى لتتمية

مهار ات المبادرة التفاعلية لدى طفل الروضة ؟

\section{أهداف البحث}

1- تحديد بعض مهار ات المبادرة التفاعلية المناسبةً لطفل الروضة من سن

$$
\text { (7-0) }
$$

ץ-تحديد مدى إمكانية تتمية مهار ات المبادرة التفاعلية المناسبة لطفل

$$
\text { الروضة }
$$

ب- إعداد وتصميم برنامج قائم على اللعب التمثيلى في تتمية مهار ات المبادرة التفاعلية لدي طفل الروضة.

ع- التعرف على فاعلية استخدام اللعب التمثيلى في تتمية مهار ات المبادرة التفاعلية لدي طفل الروضنة.

\section{أهمبة البحث:}

1- تعد الدر اسة استجابة للاتجاهات الحديثة المناديــة بــضرورة الاهتمــام

بالأطفال بصفة عامة و أطفال الروضة بصفة خاصة . 
ץ- تحديد أبعاد المبادرة التفاعلية لأطفال الروضة ومن ثم تضمينها البر امج التعليمية فى رياض الأطفال.

س- إمداد المجال بأنشطة اللعب التمثيلى اللازمة لتنمية المبــادرة التفاعليــة لدى أطفال الروضة . ع- تتمية الجانب المهارى مما يساعد على تجنب الوقوع فـى المــشكلات الاجتماعية لدى أطفال الروضة.

اقتصر البحث الحالى على الحدود التالية : 1- عينة من أطفال الروضة للتعلم بإحدى رياض الأطفال . r- مجموعة من أطفال الروضة بمحافظة الدقهلية من روضة التمد بالسنبلاوين وتضم المجموعة التجريبية ، وروضه كفر عبد الأمين بالسنبلاوين وتضم المجمو عة الضابطة.

\section{منهج البحث}

المنهج الوصفى : الأى تمنل فى استقراء الأدبيات و البحوث و الدراسات السابقة فى الإطار النظرى و إعداد أدوات البحث وتحليل نتائج البحث ومناقشتها وتفسير ها .

المنهج التجريبى : بغرض دراسة فاعلية اللعب التمثيلى فى تتمية

المبادرة التفاعلية لدى أطفال الروضة من خلال مجمو عتى البحث . 
المجموعة التجريبية : مجموعة من أطفال الروضة يتم تعليمهم من

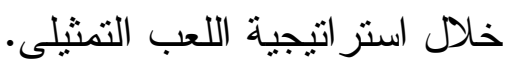

المجموعة الضابطة : مجموعة من أطفال الروضة يتم تعليمه من

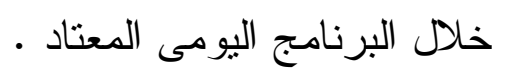

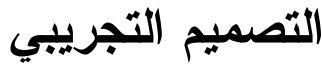

وقد اشتمل التصميم التجريبى للبحث على المتغير ات الآتية :

• متغير مستقل : استر اتيجية اللعب التمثيلى.

• متغير تابع : المبادرة التفاعلية

مصطلحات البحث

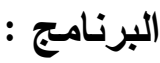

يعرف البرنامج إجرائًا في البحث الحالي بأنه : مجموعة من الأنـشطة

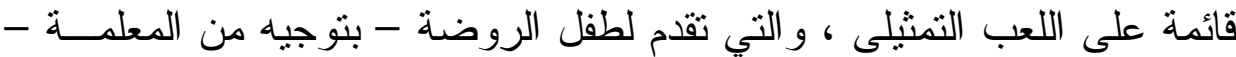

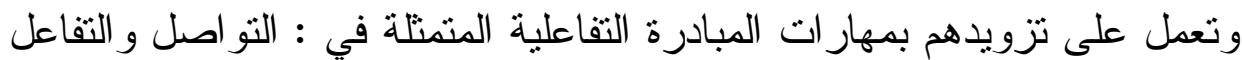
الاجتماعي ، النظافة ، الإلتز ام بالقو اعد و التعليمات ، المحافظة على المنلكات،

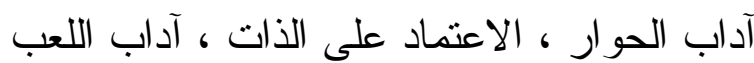

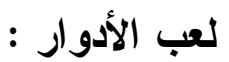

يعرف اللعب التمثيلى إجرائيًا في البحث الحالي بأنه : طريقــة للـتـعلم تعتمد على اللعب التمثيلى بين أطفال الروضة وذللك من خلال مجموعاتهم التـي بـي

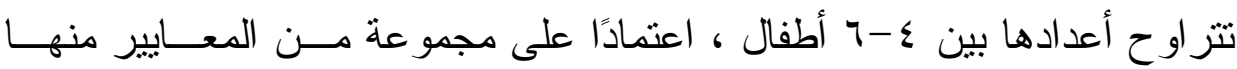


المبادرة الايجابية و التو اصل و التفاعل وجهًا لوجه وينم ذللك تحــت إثـــر اف و توجيه المعلمه لتحقيق الأهداف المرجوة •

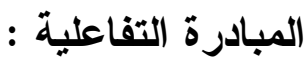

تعرف مهارات المبادرة التفاعلية إجرائيًا في البحـــث الحــالي بأنهــا :

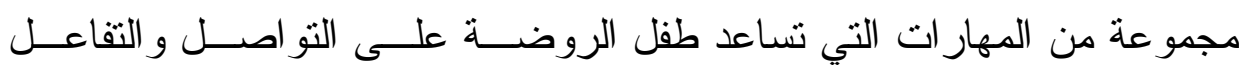
الاجتماعى في الكثثر من الأمور الاجتماعية.

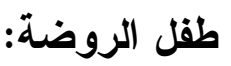

يعرف طفل الروضة إجرائيًا في البحث الحالي بأنه : هو الطفـلـل الـــى

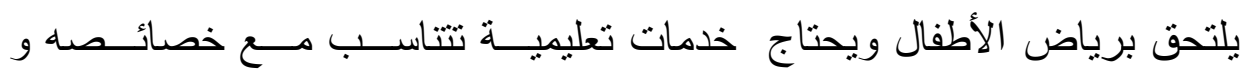

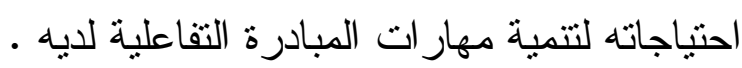

\section{فروض البحث}

ا-نوجد فروق ذات دلالة إحـصائية بـين منوســـي درجــات أطفــال المجموعتين التجريبية و الضابطة في التطبيق البعدي لـقياس المبــادرة التفاعلية المصور لطفل الروضة لصالح المجموعة التجريبية. ץ- توجد فروق ذات دلالة إحصائية بين متوسطي درجات أطفال المجموعة التجريبية في التطبيقين القبلي و البعـدي لمقيــاس المبــادرة التفاعليــة المصور لطفل الروضة لصالح النطبيق البعدي بعد البرنامج.

$$
\text { أدوات البحث }
$$

1- استبانه تحديد مهار ات المبادرة التفاعلية المناسبة لأطفال الروضة .

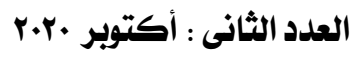


r- بقياس أبعاد المبادرة التقاعلية .

ץ- برنامج مقترح قائم على اللعب التنثيلى لتتمية مهار ات المبادرة التفاعلية

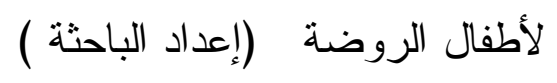

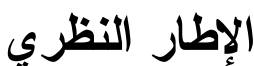

المحور الأول : اللعب التمثيلى

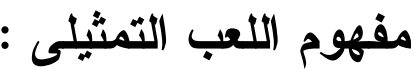

ويعريّف اللعب التمثيلى بأنه : " أحد الأنشطة التعليمية التي تعتمد على

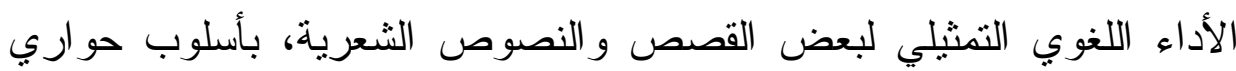

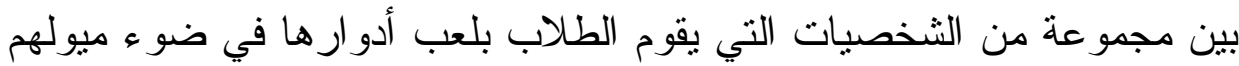

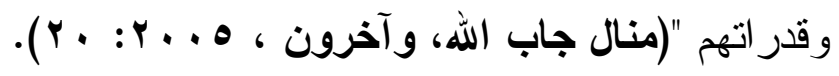

وفيه يقوم الطفل بتمثيل الموقف المر اد تعلمه من المهارة وذلك عن طريق

مشاهدة النماذج الحية أو غير الحية ومحاولة تقليد النموذج، إذ يقوم الطفل بملاحظة المهارة المطلوب تعلمها و أعاده هذه المهارة مرة أخرى، وممارسة كل عضو للمهارة على حدة لبيان ددى نجاحه في اكتساب المهارة. (أماني عبد

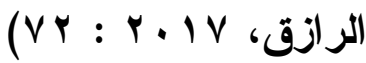

ويعرف اللعب التمثيلى إجرائيًا بأنه : طريقة للتعلم تعتمد علـى تمثيــل

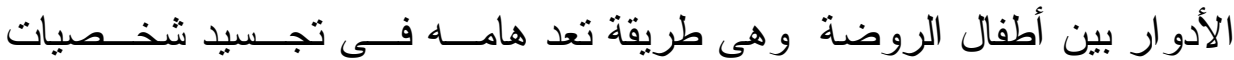

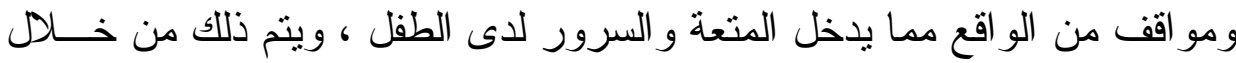
تقسيم الأطفال فى مجموعات بتر اوح إعدادهم فيما بين ع - ج أطفــال اعتمـادًا 
على مجموعة من المعايير منها المبادرة الايجابية و التو اصل و التقاعـلـل وجهً لوجه ويتم ذلك تحت إثر اف و توجيه المعلمة لتحقيق الأهداف المرجوة -

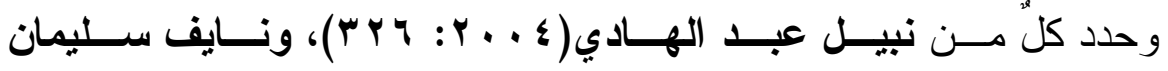

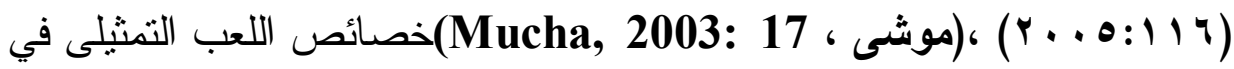

- يتحدد اللعب التمثيلى بطبيعة الطفل الاجتماعية. - له علاقة بالثقافة الاجتماعية للطفل، ويرتبط بطبيعة المرحلة العقلية التي

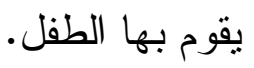

- - التلقائية و الارتجالية، حيث يتم تمثيل الأدوار دون الإعداد المسبق ويترك المجال لمن يقوم بتقمص الأدوار بالتعبير الحر دون قيد عما يشعر به

$$
\text { ويحسه ويعتقده. }
$$

- يتتاول من يقوم باللعب التمثيلى تقص شخصيات و اقعية في البيئة ومشكلات معاصرة تثير اهتمام المشاهدين كالنظافة و المياه و الصحة

$$
\text { و غير ها. }
$$

أهداف اللعب التمثيلى :

يهدف اللعب التمثيلى إلى تتمية إتجاهات الأطفال في معالجة المـشكلات الحياتية و الاجتماعية اليومية، ولما كان اللعب التمثيلى يستتد إلى قــدرة الطفـلـل

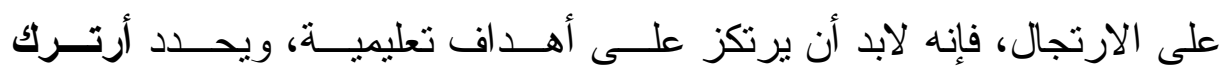
(Eurturk, 2015: 8) تتمية روح التعاون و العمل في فريق • 
> الربط بين النظرية و التطبيق، بنقريب المفاهيم المنهجية النظرية إلى و اقع الحياة الاجتماعية التي يعيشها الطفل.

إكساب الطفل فرصة للتدريب على أدو ار حياتية كثيرة، وذلك من خــادل

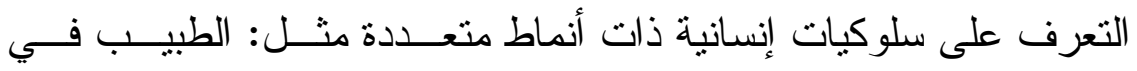
العيادة، و الأب و المعلمة كلٍ في وظيفته في المجتمع. > توظيف المهار ات اللغوية و الفكرية و الحركية. > مساعدة الطفل على فهم ذاته وفهم الآخرين.

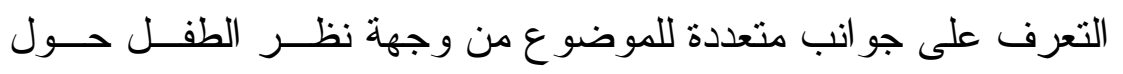
الموضوع نفسه. دور المعلمة فى استخدام اللعب التمثيلى :

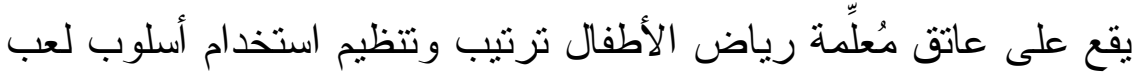

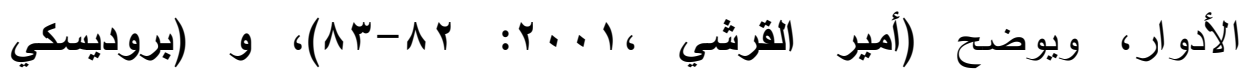

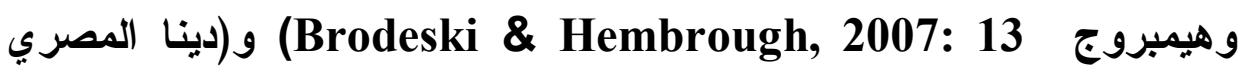

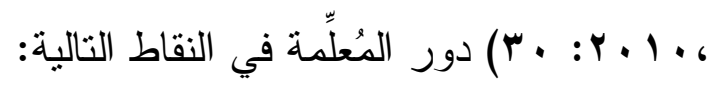
> تحديد وتوفير الوقت المناسب للعب الأدوار، لأن الإسر اف في ممارســـة

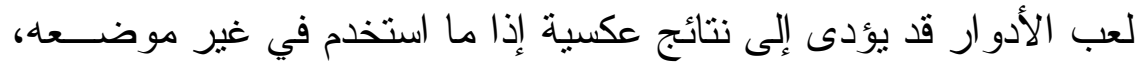

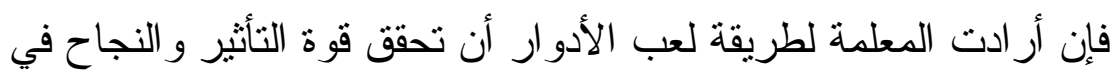

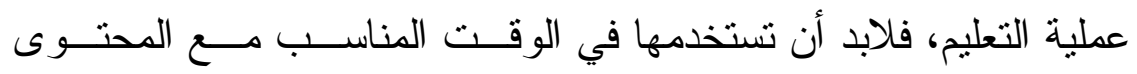

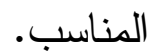


ضرورة توخى الدقة و الصدق عند قيــام الأطفــال بتجـسيد الأحسـداث،

و الثخصيات من خلال تحديد معالم الثخصيات بدقـه، وتوضـيح خـط سـير

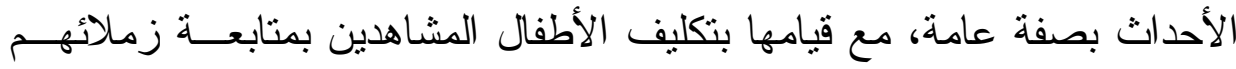

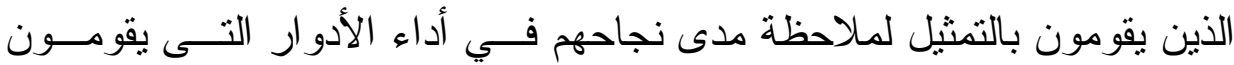
بتمثيلها

المحور الثانى : المبادرة التفاعلية المبادرة التفاعلية هى أحد مكونات المهار ات الإجتماعية، وهى تعني قدرة

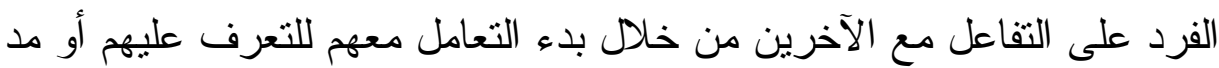

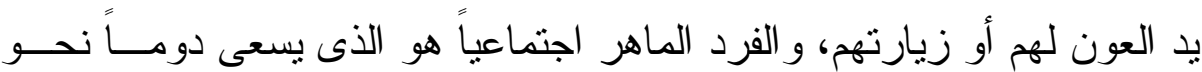

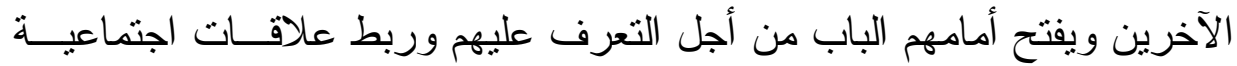

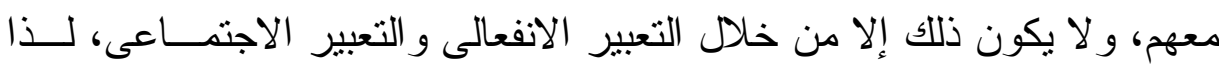

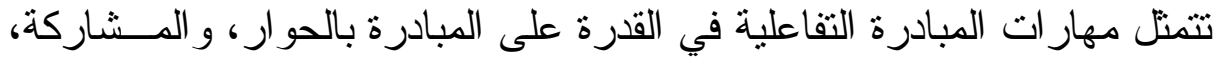

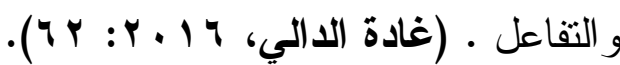
وتعرف المبادرة التفاعلية إجرائيا : مجموعة من المهار ات التي تـساعد

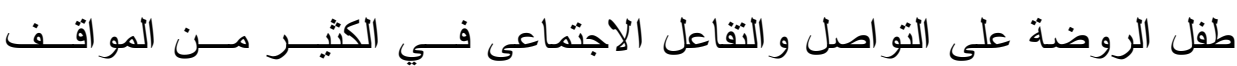

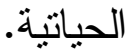

\section{خصائص المبادرة التفاعلية}

تتميز مهارة المبادرة التفاعلية - بعدة خصائص حددها كلٌ من : (معتز

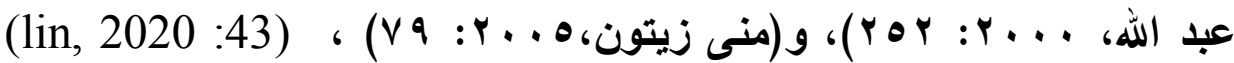
فيما يلي :

\begin{tabular}{|c|c|}
\hline r.r. العدد الثانى : أكتوبر & $r \cdot r$ \\
\hline r & \\
\hline
\end{tabular}


( ) تتميز مهارة المبادرة الثفاعلية بالبراعة Proficiency والكفاءة و والخبرة Competence الاجتماعية، ومختلف أنثكال تفاعلاته مع الآخرين .

r العنصر الجوهري في أي مهارة اجتماعية هو القدرة على تحقيق نتيجة

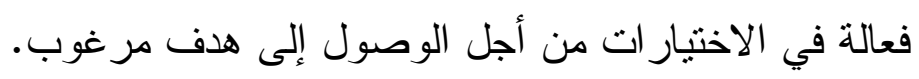
r) تشتنل على قدرة الطفل على الضبط المعرفي لسلوكه. ؟) تتضمن مكونات لفظية و غير لفظية. 0) تتأثر بخصائص الأفراد الموجودين في الموقف الاجتماعي كالعمر،

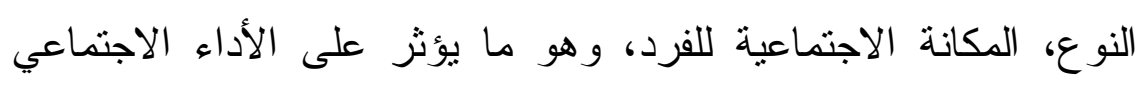
للفرد. 7) يمكن تحديد مواطن القصور في الأداء الاجتماعي . أهمية المبادرة التفاعلية

تلعب مهار ات المبادرة التفاعلية دوراً كبيرًا ومؤثراً ليس فقط في حياة

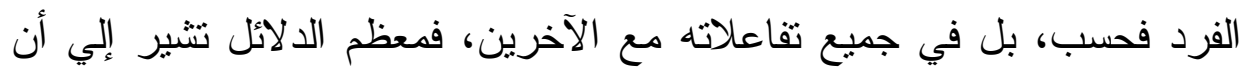
الناس المهرة اجتماعياً، والذين يعرفون كيف يتحكمون في مشاعرهم جيداً

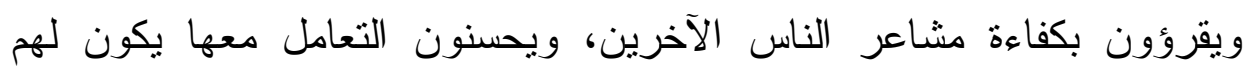

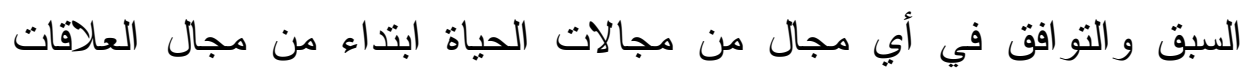
العاطفية إلي الالتزام بالقو اعد غير المكتوبة التي تحكم النجاح في عمل سياسات

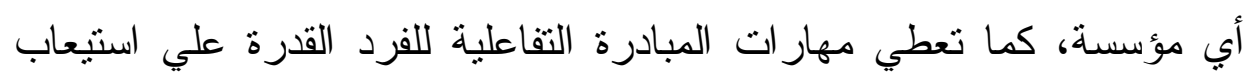

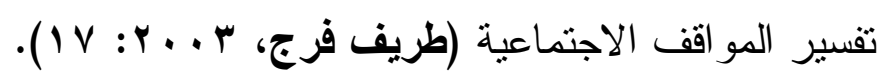

r.r.r. العدد الثانى : أكتوبر

$r \cdot \varepsilon$

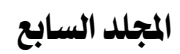


وتتمنل أهمية مبادرة الطفل بالتفاعل مع الأقران، كما حددها كل" من

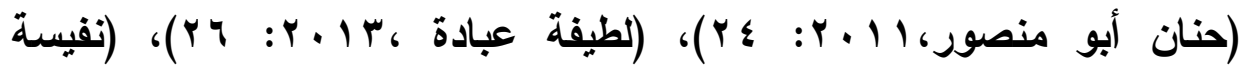

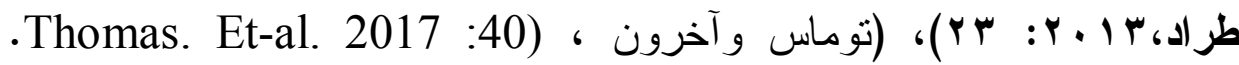

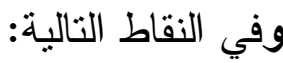

() تسهم المبادرة التفاعلية في تكوين سلوك الطفل، فمن خلالها يكتسب الوليد البشري خصائصه الإنسانية ويتعلم لغة قومه وثقافة مجتمعه وقيمها و عاداتها وتقاليدها، من خلال عملية التطبع الاجتماعي. Y المبادرة التفاعلية ضرورة مُلحَّهَ للقدرة على بناء و إدارة العلاقات

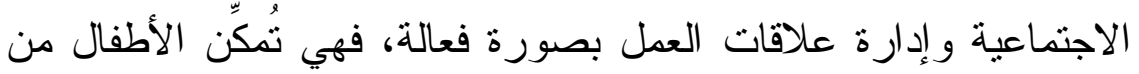

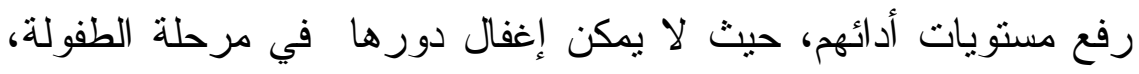

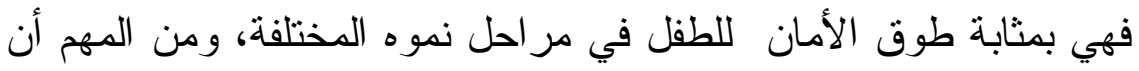

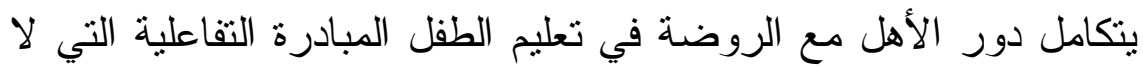

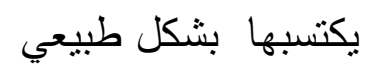
مهارات المبادرة التفاعلية المناسبة لطفل الروضة 1) مهارة التو اصل و التفاعل الاجتماعي

تعد مهار ات التو اصل و التقاعل الاجتماعي هي أي مهارة تُكَّن الإنسان

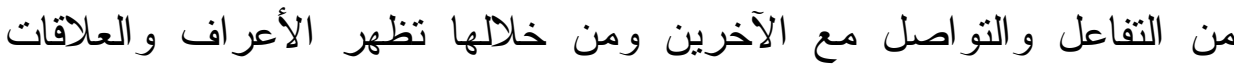
الاجتماعية من خلال عدة صور لفظية أو غير لفظية، والغرض من الاتصال

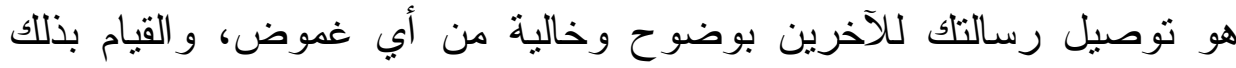

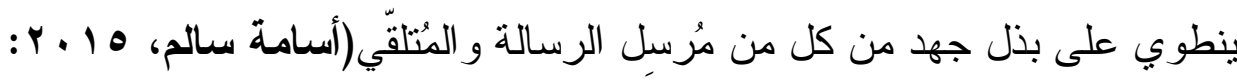


وقد روعى فى البرنامج تنمية مهارة التواصل والتفاعل الاجتماعي لاى طفل

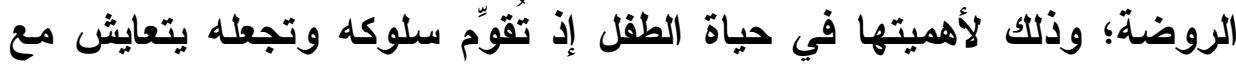
الآخرين في البيئة المحيطة به، ومن صور مهارة التواصل والتفاعل

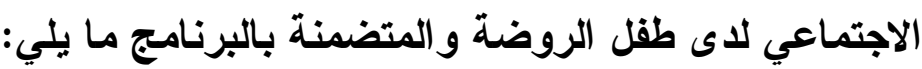

- يشارك فى الأعياد و المناسبات المختلفة ( عيد الأم ـ سبوع المولود ـ فرح .... الخ ).

- يقيم علاقات صداقة مع أقر انه (أطفال الجيران ، زملائه بالروضة .... ألخ - يحسن الاتصال بأفر اد الأسرة و الجيران . - يسنطيع التعبير عن مشاعرهو أفكاره . - يظهر الثكر و الامتتان عندما يقدم له شخص شيئًا ما.

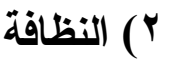

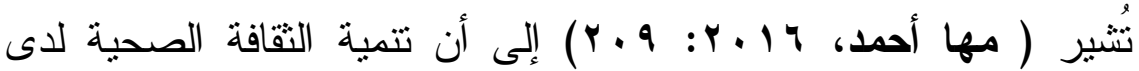
الأطفال تهدف إلى : - إنى

نثر المفاهيم الصحية السليمة في المجتمع وتحسين صحة الفرد و المجتمع، ممارسة العادات الصحية السليمة التي تساعد الطفل على المحافظة على حالته الصحية، ترسيخ السلوكيات الصحية السليمة ، البعد عن السلوك الذي يضر بالطفل أو بالآخرين.

r.r.r. العدد الثانى : أكتوبر

r.T

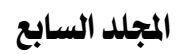


ويمكن توضيح أنه قد روعى فى البرنامج القائم على لعب الأدوار إعداد

أنثطة تهاف لتنمية مهارة النظافة لاى طفل الروضة؛ وذلك لأهميتها في حياة الطقل إذ تُقوّم سلوكه وتجعله يتعايش مع الآخرين في البيئة المحيطة به، ومن صور مهارة النظافة لاى طقل الروضة ما يلي: - - يغسل أسنانه دون مساعدة - - يغل يديه عند الحاجة دون تتبيه من أحد - - ينظف نفسه بعد استخدام الحمام - يحافظ على نظافة المكان الذى يتو اجد فيه (المنزل ـ ـ الروضة ــ فناء الروضة ) - بشارك زملاءه فى تتظيف القاعة وتجميلها تعرف بأنها مجموعة قو اعد ســلوكية للحفــاظ علــى النظــــام و التبعيــة

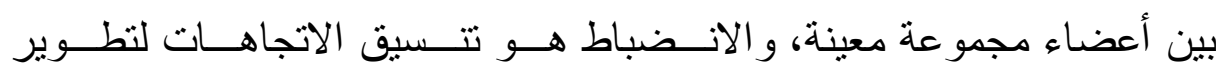

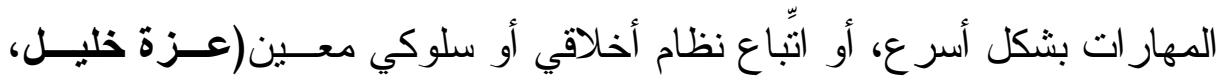

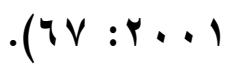

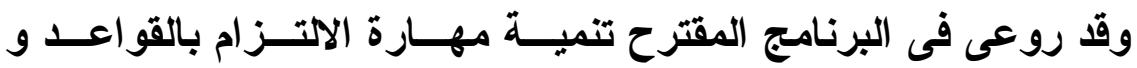

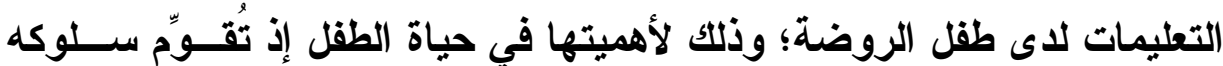

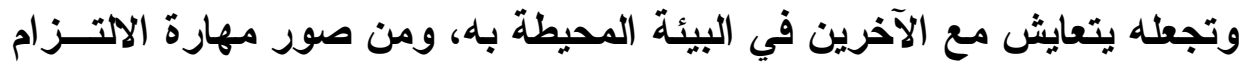

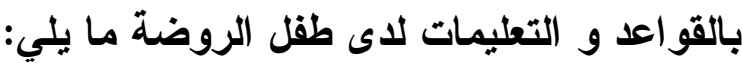




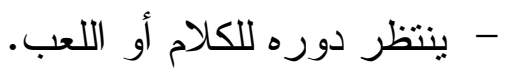

- يتقبل التعليمات ويلتزم بها من الأشخاص المعروفين لديه

$$
\text { - - يتبع الأو امر بالترتيب الذى أعطيت به }
$$

تضمّ المنلكات العامة المباني و المنشآت المختلفة، و الحدائق و الملاعب

و الدكتبات، ومواقف السيار ات، بالإضافة إلى الحافلات، و المرافق الصحيّة،

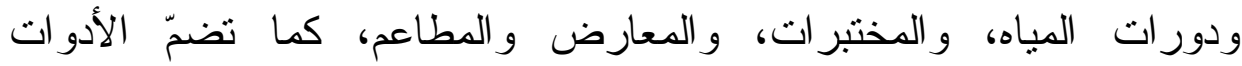

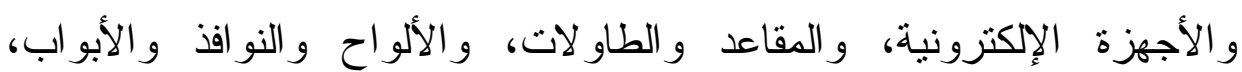

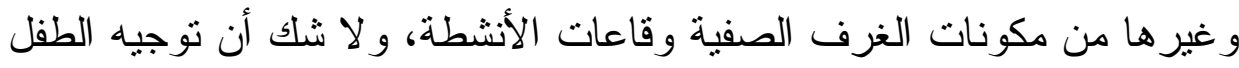

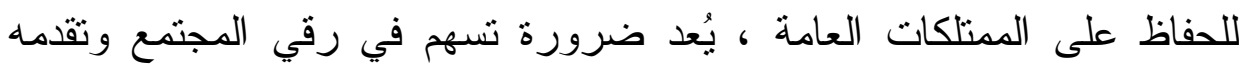

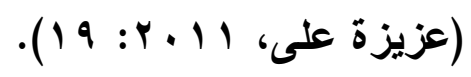

وقد تم الاستعانه فى البرنامج المقترح بالعديد من الأشطة القائم على

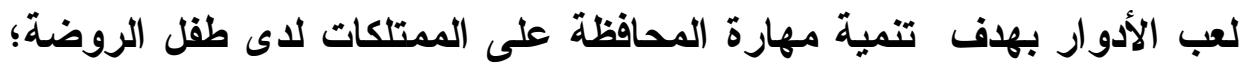

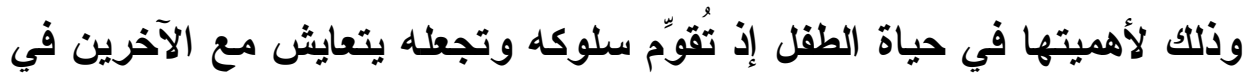
البيئة المحيطة به، ومن صور مهارة المحافظة على الممتلكات لاى طقل الروضة ما يلي: البئة المحيطة

$$
\text { - - يحافظ على ممتلكاته الثخصية }
$$

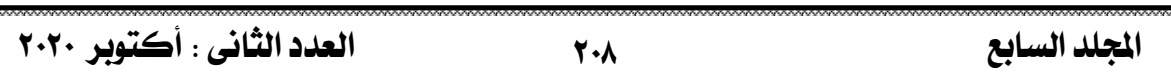


7) الاعتماد على الأات

يُعد الاعتماد على الذات من المهار ات الضرورية المراد اكسابها في مرحلة رياض الأطفال، حيث أنه ينتج من خلال تكيف الطفل مع بيئته و التعامل مع المو اقف الحياتية، و أيضا من خلال التشجيع المستمر (محمد يوسف، 9 . . ؟ :

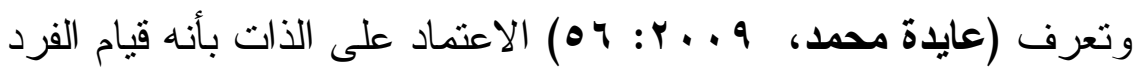

بدور إيجابي وهام نحو الجماعة، ومعرفته لحقوقه وو اجباته داخلها من خلال المو اقف التي يتعرض لها، كما أن تحمل المسئولية هي تطوير شخصية الطفل وتتظيم ذاته من خلال القدرة على القيام ببعض السلوكيات و الأعمال ومحاولة حل المشكلات دون مساعدة الآخرين.

وقد روعى فى البرنامج المقترح استخدام العديد من الأنشطة القائمة على لعب الأدوار لتنمية مهارة الاعتماد على الأت لاتى طقل الروضة؛ وذلتك لأهميتها في حياة الطقل إذ تُقوّم سلوكه وتجعله يتعايش مع الآخرين في البيئة المحيطة به، ومن صور مهارة آداب الاعتماد على الذات لاى طقل الروضة ما يلي: - يعتمد على نفسه فى أداء ما بطلب منه من الأعمال - يعتمد على نفسه فى ترتيب حجرته بنفسه. - يعتمد على نفسه فى تتاول الطعام - يعتمد على نفسه فى لبس ملابسه بالكامل (تزرير الزر اير ، عقد الأربطة إلخ....6 
اللعب هو استغلال الطاقة الحركية و الذهنية في آنٍ و احد عبر نشاطٍ ما، قد يكون موجهاً أو غير موجه، يقوم به الأطفال عادةً لتحقيق المتعة و التسلية

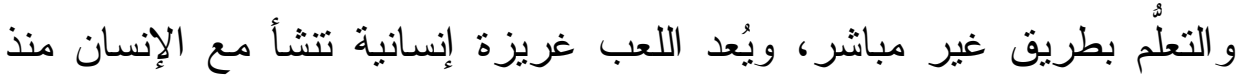
لحظات و لادته الأولى، ويكتسب الطفل من خلاله أنماطاً سلوكية تتعكس على الى المو اقف التي تواجهه في مر احل مقبلة من العمر . وقد يكون اللعب على شكل حركة أو عمل يمارس فردياً أو جماعياً، ويستغل طاقة الجسم الحركية و الذهنية، ويمتاز بالسرعة و الخفة، و لا يُتعب صاحبَه، و لا يهدف إلا إلى الاستمتاع (فهيم

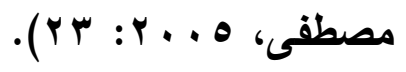

وقد روعى فى البرنامج المقترح تنمية مهارة آداب اللعب لاى طقل الروضة؛ وذلك لأهميتها في حياة الطقل إذ تُوِّم سلوكه وتجعله يتعايش مع الآخرين في البيئة المحيطة به، حيث تضمنت أنشطة لعب الأدوار تنمية مهارة آداب اللعب لاى طقل الروضة من خلا تضمينها بعض السلوكيات المتمثلة

الاستئذان قبل استخدام أدوات ولعب الغير ، وتقبل مشاركة الآخرين فى لعبته ،ومشاركة أقرانه فى ألعاب تنافسية (لعبة شد الحبل ــ لعبة كرة السلة

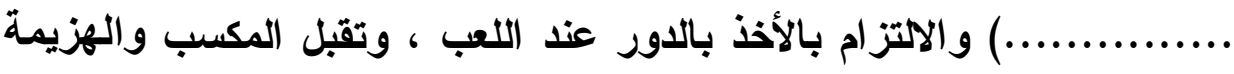

تم تطبيق إجر اءات البحث في الفصل الدراسي الأول من العام الدر اسي

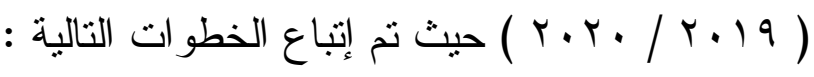

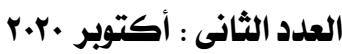


أولاً : الإطلاع على المر اجع العربية و الأجنبيــة التــي اهتمــت بمهــار ات

المبادرة التفاعلية لدى طفل الروضة.

ثانيًا : إعداد قائمة بمهار ات المبادرة التفاعلية التي يمكن تتميتها لــدى طفـلـل الروضة ، وذللك استتادًا إلى ما تم التوصل إلبه في الخطوة السابقة ، ثم عرض هذه القائمة من خلال استبانة على مجموعة من المحكمين فـي

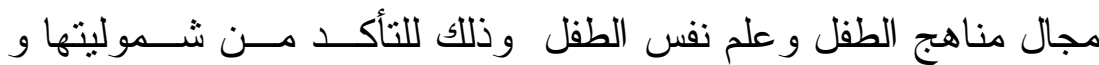
موضو عيتها ، ومدى إمكانية تتمية هذه المهار ات لدى أطفال الروضـــة

ثالثًا : تصميم برنامج مقترح لتنمية مهار ات المبــادرة التفاعليــة - الــسابق تحديدها - لدى أطفال الروضة من خلال إستر اتيجية لعب الإدوار . رابعًا : ضبط البرنامج من خلال عرضه على مجموعة من المحكمين وتعديله في ضوء آر ائهم ووضعه في صورته النهائية . خامسًا : إعداد مقياس لقياس مدى اكتساب أطفال الروضـة لمهار ات المبــادرة التفاعلية التي يتضمنها البرنامج المقتر ح ، و إجر اء الضبط العلمي لهـذذا

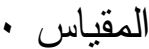

سادسًا : اختيار عينة البحث من مدرسة روضة التمد وروضـــة كفــر عبــد

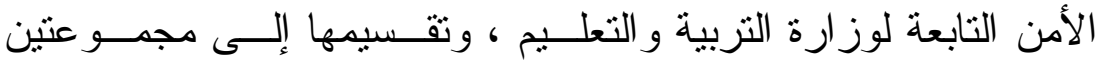
• إحداهما ضابطة الأخرى تجريبية سابعًا : تطبيق مقياس مهار ات المبادرة التفاعلية قبليًا علــى عينــة البحــث ( المجموعة التجريبية و المجموعة الضابطة ) ) 
ثامنًا : تطبيق البرنامج المقتر ح على المجموعة التجرييية .

تاسعًا : نطبيق مقياس مهار ات المبادرة التفاعلية بعديًا علــى عينــة البحــث

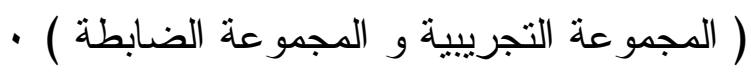

عاشرًا : جدولة البيانات و معالجتها إحصائيًا ، ثم تحليل النتائج وتفسيرها في

$$
\text { ضو اء مشكلة البحث و فروضه }
$$

حادي عشر : تقديم التوصيات و الدر اسات الدقترحة .

$$
\text { وفيما يلي شرح تفصيلي لكل خطوة : }
$$

أولاً : استبانة تدديد المهارات الاجتماعية التي يجب توفرها لاى طقل الروضة

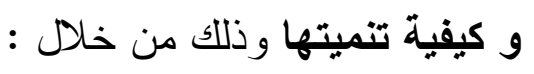

ه الاطلاع على المر اجع العربية والأجنبية التي تتاولت مهار ات المبــادرة

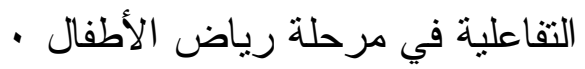

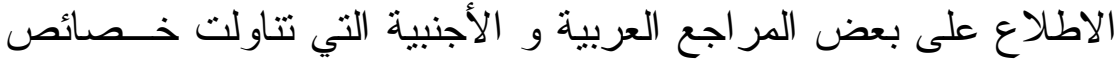

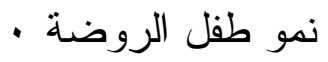

ثانيًا : في ضوء الخطوات الـسابقة تــم إعـــداد قائمــة بمهــارات المبــادرة التفاعلية المناسبة لطفل الروضة ، حيث نم تقسيمها إلى الدحاور السبعة 
جدول (1)

يوضح محاور استبانة مهارات المبادرة التفاعلية و الفرعية

\begin{tabular}{|c|c|c|}
\hline مهارات المبادرة التفاعلية & مهارات المبادرة التفاعلية & $p$ \\
\hline تتضمن (0) مهار ات فرعية & التو اصل و التفاعل الاجتماعى & 1 \\
\hline تتضمن (0) مهار ات فرعية & النظافة & Y \\
\hline تتضمن (ع) مهار ات فرعية & الالتز ام بالقو اعد و التعليمات & $r$ \\
\hline تتضمن (0) مهار ات فرعية & المحافظة على الممنكات & $\varepsilon$ \\
\hline تتضمن (0) مهار ات فرعية & آداب الحوار & 。 \\
\hline تتضمن (ع) مهار ات فرعية & الاعتماد على الذات & 7 \\
\hline تتضمن (0) مهار ات فرعية & آداب اللعب & 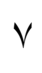 \\
\hline بr مهارة فرعية & مجـــ & \\
\hline
\end{tabular}

وبذلك يكون عدد المهارات الفرعية التي تتدرج تحت المحاور الرئيـسية

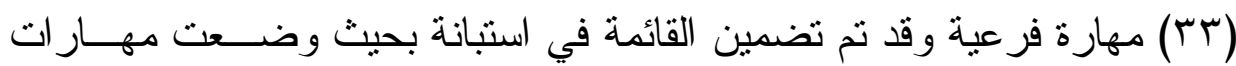

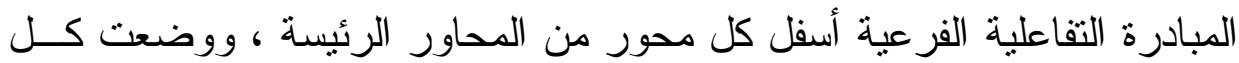
مهارة رئيسية و المهار ات الفرعبة المرتبطة بها أمام مقياس من ثلات مستويات

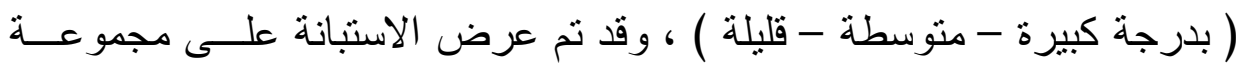

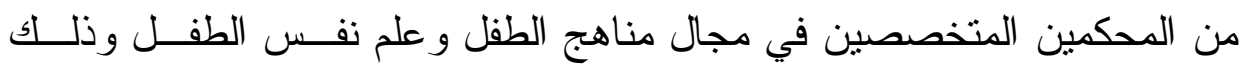
لمعرفة آر ائهم حول كل من : ل المين

- مدى أهمية كل مهارة من مهار ات المبادرة التفاعلية الفرعيــة المدرجــة تحته .

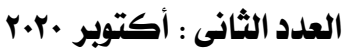


- مدى أهمية تتمية هذه المهار ات لأطفال الروضة - مدال

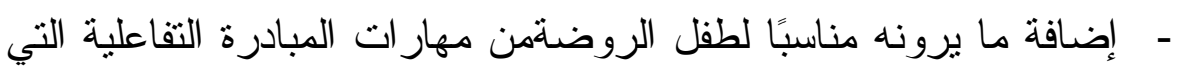

$$
\text { يجب تتميتها لديه ولم يتم تضمينها في الاسنبانة مئن }
$$

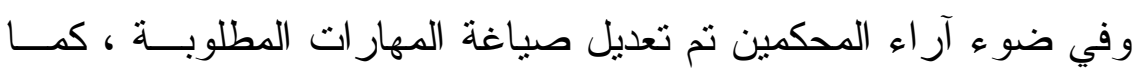

اتضـح أن جميع مهار ات المبادرة التفاعلية الفرعية التي شملتها القائمــة و البــالغ

عددها (Tr) مهارة فرعية ستؤخذ جميعها في الاعتبار عند تـصميم البرنــامج المقتر ح و كذلك تصميم مقياس مهار ات المبادرة التفاعلية لطفل الروضة .

وبذلك تمت الإجابة على الـسؤ ال الأول مــن أســـلة البحـــث ؛ حيــث

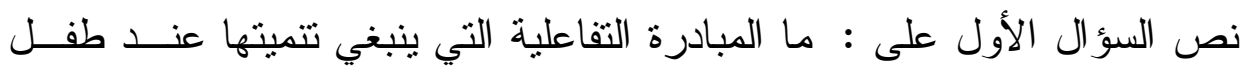

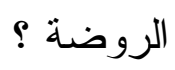

ثالثًا : تصميم البرنامج المقترح :

يتتاول هذا الجزء خطوات بناء و تصميم البرنامج المقتـر ح وضــبطه ،

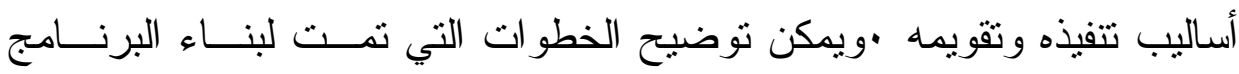

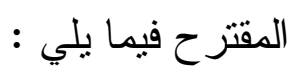

أ- أسس بناء البرنامج المقترح -

ب- تعديا الإطار العام للبرنامج ، ويثمل :

- 1 - تحديد أهداف البرنامج

r- تحديد محتوى البرنامج

ب- طرق التدريس المالائمة للبرنامج المقترح 
ع - تحديد الوسائل و الأدوات المناسبة لأنشطة البرنامج .

0 - تحديد أساليب التقويم التي يمكن استخدامها في البرنامج ·

ج-عرض البرنامج المقترح على مجموعة من المحكمين

( أ ) أسس بناء البرنامج المقترح :

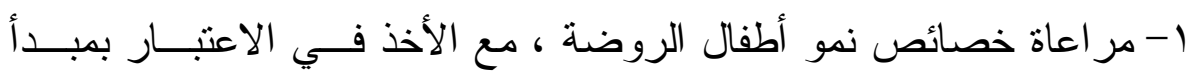

- الفروق الفردية بينهم

r- التأكيد على دور طفل الروضة وفاعليته من خلال أنشطة اللعب التمثيلـى

التي تعتمد على المبادرة فيما بينهم - مانه

ب- توفير الوسائل و الأدوات و الخامات بما يتتاســب و طبيعــة الأنـشطة

المستخدمة في البرنامج المقتر ح

ع- إتاحة الفرصة الكافية لجميع الأطفال سواء بصورة فرديــة أو جماعيــة

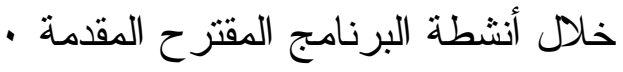

0- مر اعاة استمر ارية و تكر ار مهار ات المبادرة التقاعلية الفرعية المقدمة في البرنامج المقترح ، بهدف إتاحة الفرص لطفل الروضة لتوظيف ما تعلمه

$$
\text { من مهار ات في مو اقف مشابهة مات }
$$

צ- استخدام وسائل و أساليب التقويم المناسبة لقياس نو اتج الــتعلم بالبرنــامج

- المقتر ح

V- مر اعاة التتوع في أنشطة اللعب التمثيلى بحيث تعمل على مر اعاة الفروق

الفردية و تحقيق مبدأ تكافؤ الفرص لجميع الأطفال مرال

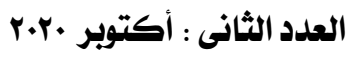


(ب) تدايد الإطار العام للبرنامج المقترح ، ويشمل :

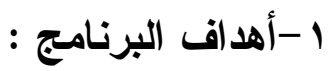

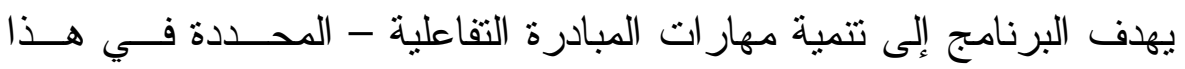

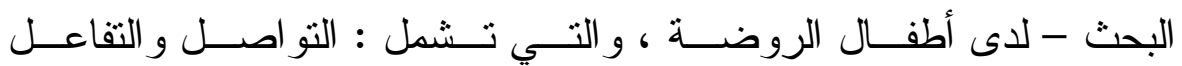

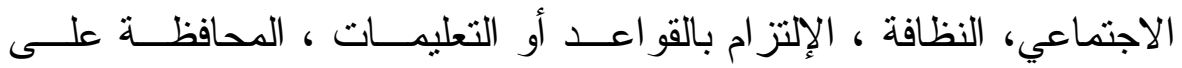

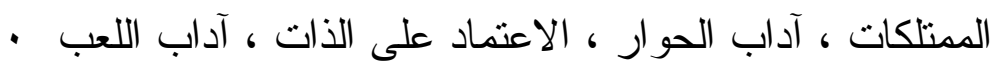
r - ب - محتوى البرنـامج :

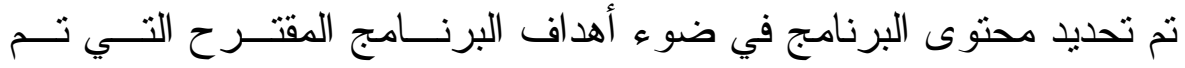
تحديدها و استتادًا إلى ما توصل إليه من خلال الإطار النظري و الدر اســات

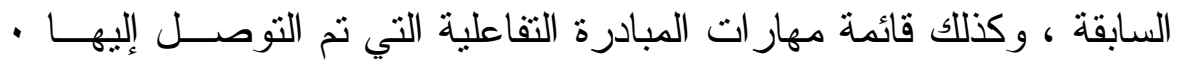
وبناء على ذللك فقد تم تصميم محتوى البرنامج في صورة مجموعة الأنشطة

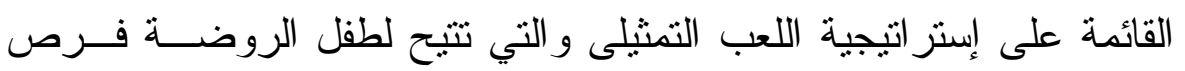

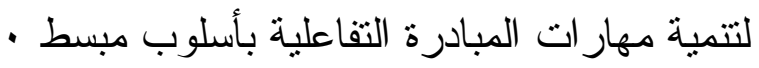
ب- طرق التعليم الملائمة للبرنامج :

في البحث الحالي تم استخدام طريقة التعليم التي اعتمدت على إبــتر اتيجية اللعب التمثيلى في تتفيذ البرنامج المقترح الذي يشتمل على مهار ات المبادرة التفاعلية كأساس لمحتو اه. ع - الوسائل والأدوات المستخدمة :

روعي عند تصميم البرنامج المقتزح المبادرة باستخدام وســائل متتوعــة و مشوقة لجذب الانتباه بما يتتاسب مع تتمية مهار ات المبادرة التفاعليــة مــن خلال إستر اتيجية اللعب التمثيلى وقد اشتملت الوسائل و الأدوات و الخامـات 


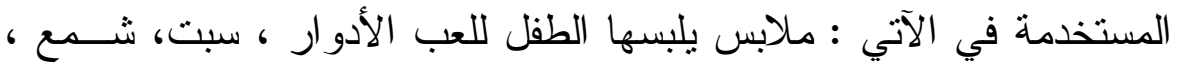

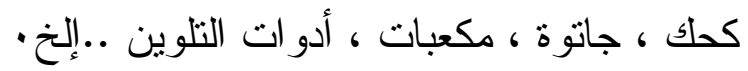

$$
\text { ه-أساليب تقويم البرنامج : }
$$

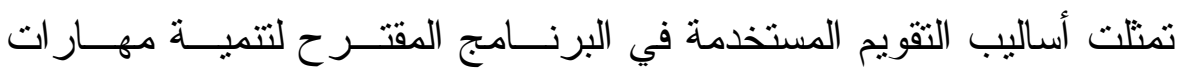
المبادرة التفاعلية عند طفل الروضة فيما يلي :-

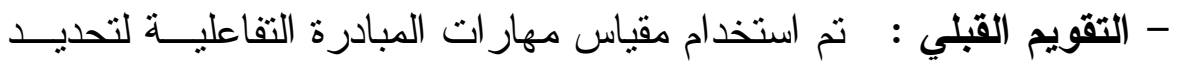

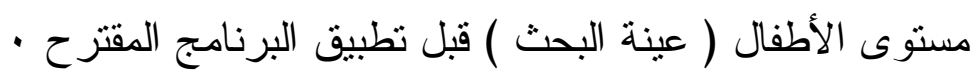

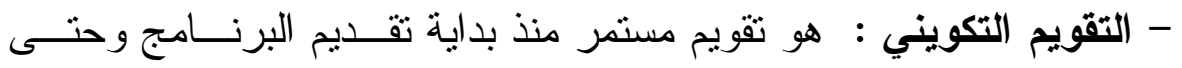

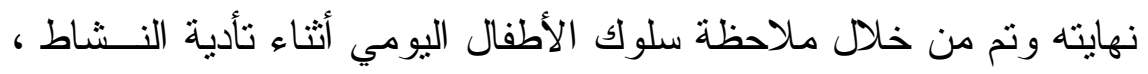

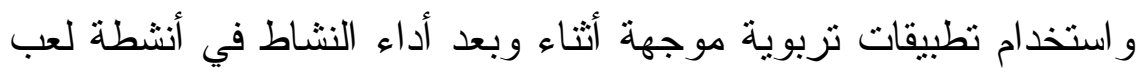

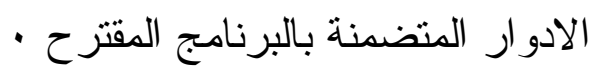
- التقويم النهـائي : تم استخدام مقياس مهار ات المبادرة التفاعلية لتحديــــ مدى ما اكتسبه أطفال المجموعة التجريية من مهار ات المبادرة التفاعلية

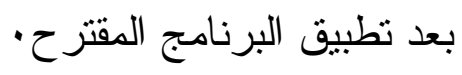
رابعًا : عرض البرنامج المقترح على المحكمين :

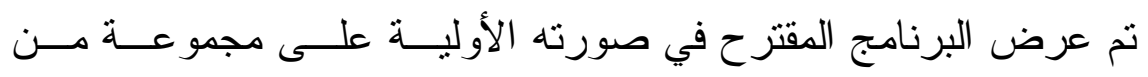

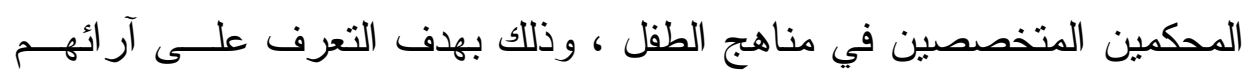

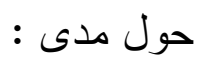

- - مناسبة البرنامج المقترح لتتمية مهار ات المبادرة التفاعليـــة لــدى طفـلـل الروضة 
- صحة البرنامج من حيث : الأهداف ، عناصر المحتوى ، مدى ملائمـــة المادة العلمية، مدى ملائمة الأنشطة للمهار ات التي تتدرج تحتها ووسائل كل

$$
\text { - التقويم }
$$

وقد أبدى السادة المحكمين بعض الماحظات ، وتتلخص فيما يلي :

تعديل صياغة بعض العبار ات في الأنشطة ، تعـديل توزيــع وترتبــب

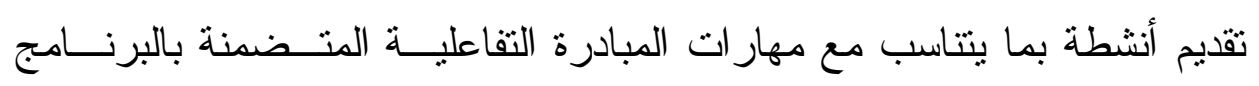

وفي ضوء مقترحات المحكمين تم إجر اء التعــديلات اللازمــة و أصــبح

• البرنامج في صورته النهائية وصالحًا للتطبيق

ويذلك تمت الإجابة على السؤال الثالث والأي ينص على ما يلي :

ما البرنامج المقترح لتتمية مهار ات المبادرة التفاعلية لدى طفل الروضة ؟

خامسًا : إعداد مقياس المبادرة التفاعلية :

تم اعداد مقياس لقياس مدى فاعلية البرنامج المقتر ح في تتميـــة مهــار ات

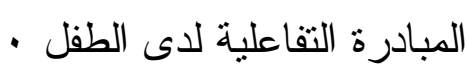

حيث يتم إعداد المقياس في ضوء مر اعاة ما يلي :

ا-الاطلاع على الدر اسات السابقة التي اهتمت بإعداد المقاييس في مجــال

$$
\text { مهار ات المبادرة التفاعلية }
$$

ب-في ضوء نتائج الاستبانة الخاصة بتحديد مهــار ات المبـــادرة التفاعليـــة

$$
\text { الو اجب نو افرها لدى طفل الروضة. }
$$

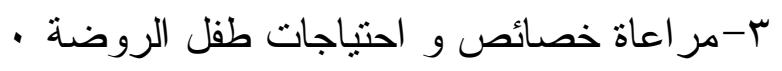


وفي ضوء الاعتبارات السابقة نم تصميم المفردات الخاصة بكل محسور

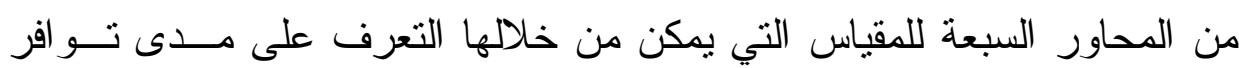

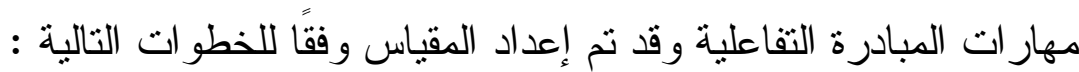

$$
1 \text { - تحديد أهداف المقياس : }
$$

يهدف هذا المقياس إلى قياس مدى تو افر مهارات المبادرة التفاعلية لــدى

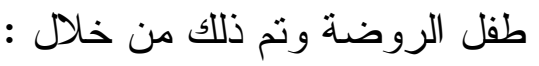

أ-استخدامه كمقياس قبلي Pre Test للتعرف على مدى تو افر مهــارات

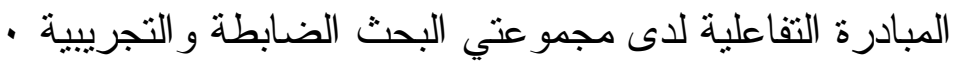

ب-استخدامه كمقياس بعدي Post Test لتقديم مدى نمو مهار ات المبادرة التفاعلية لدى أطفال المجموعة التجريبية بعد تطبيق البرنامج القائم على لغي

$$
\begin{aligned}
& \text { إستر اتيجية اللعب التمثيلى ل } \\
& \text { Y - وضع مفردات المقياس : }
\end{aligned}
$$

تم وضع مفردات المقياس بعد مر اعاة الجو انب التالية :

$$
\text { أ- تحديد نوع المقياس : }
$$

نظرًا لنقص قدرة أطفال الروضة في هذه المرحلة العمرية على القــــاءة

و الكتابة تم استخدام نمط المقياس الموضوعي الذي يعتمد على المفردات

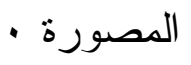

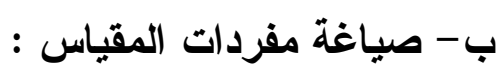

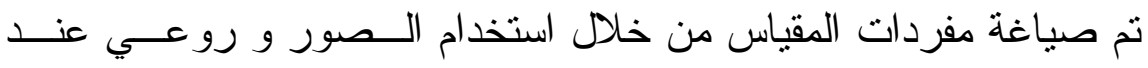

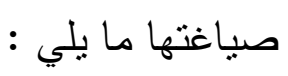

• أن تكون مرتبطة بقياس مهار ات المبادرة التفاعلية . 
أن تكون و اضحة و مناسبة لمستوى طفل الروضة بما ييسر لله فهها .

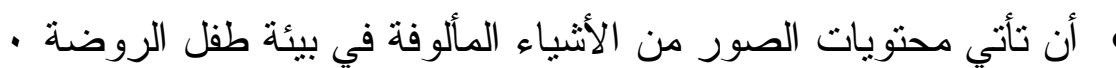

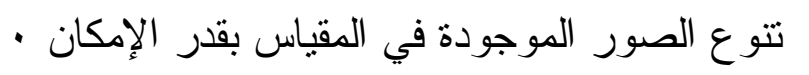

ب- تعليمات المقياس :

بلغ عدد مفردات المقياس (Tr ) مفردة ، و يتت إعطاء الطفل (1) درجـــ

في حالة وضع علامة (ل) أسفل الصورة الصحيحة (مو افق)، ويعطــي الطفـلـ

(صفر) درجة في حالة وضع علامة (ل) أسفل الصورة غير الــصحيحة (غيـر

متأكد).

ع - عرض المقياس على المحكمين :

تم عرض المقياس على مجموعة من المحكمين للتأكد من مدى صلاحيته كأداة للقياس في هذا البحث ، وذلك من خلال إبداء الر أي في : - مدى وضوح تعليمات المقياس - مدى ملائمة ووضوح الصور في المقياس أولا : معامل الصدق :

\section{: الصدق الظاهري :}

وللتحقق من صدق مقياس مهار ات المبادرة التفاعلية ، ومـــدي مناســبتها

للأغر اض الموضوعية، نم عرض المقياس فى صورته الأولية على مجموعـة من المحكمين المتخصصين من أعضـاء هيئة التذريس في مجال منـــاهج الطفــلـ و علم نفس الطفل بهدف التحقق من الصدق الظاهري للمقياس من حيث : - مدي وضوح تعليمات المقياس.

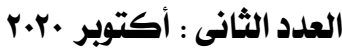


- مدي ملائمة ووضوح الصور في المقياس.

- مدي ملاءمة أسئلة المقياس المصور لأطفال الروضة.

- مدي مناسبة أسئلة المقياس المصور للهدف الذي وضع من أجله في

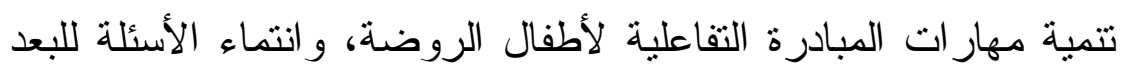

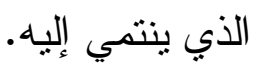

- مدي سلامة الصياغة اللغوية و العلية لأسئلة المقياس.

- تقديم أي مقترحات أو تعديلات من شأنها أن تثري أداة البحث من أجل الوصول إلى صورة صادقة للمقياس.

وقد أبدى المككمون آراءهم حول مــدى وضــوح المقيــاس المـصور

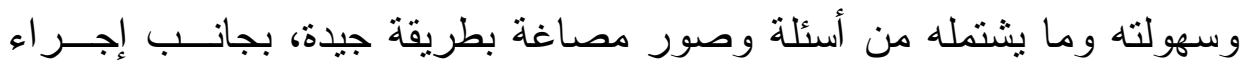

بعض التعديلات المطلوبة وكان من أهمها :

- تغيير بعض الصور لعدم وضوحها ودقتها بمـــا يتتاســب مــع أطفــال

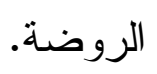

- ضرورة طبع المقياس بالألو ان لسهولة رؤية الصور .

- مر اجعة بعض الصياغات اللغوية لبعض مهار ات المقياس المصور .

وقد قامت الباحثة بــإجر اء التعـديلات المطلوبـــة و اعتبــرت الباحثــة

آراء المحكمين وتعديلاتها دلالة على صدق محتوي مقياس مهـار ات المبــادرة 
صدق الاتساق الداخلي أو التجانس الداخلي لمفردات مقياس

\section{مهارات المبادرة التفاعلية المصور :}

بعد التأكد من الصدق الظاهري لمقياس مهـار ات المبــادرة التفاعليــة المصور عن طريق المحمين، نم تطبيق المقياس على عينة استطلاعبة من غير

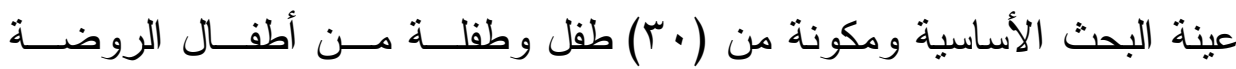

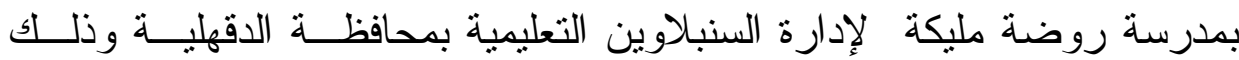

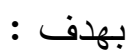

1- حساب صدق الاتساق الـــاخلي لمقيــاس مهـــار ات المبــادرة التفاعليــة

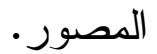

r- حساب ثبات مقياس مهار ات المبادرة التفاعلية.

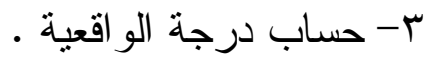
ع - حساب زمن مقياس مهار ات المبادرة التفاعلية المصور .

$$
\text { وفيما يلي تفصيل ذلك : }
$$

أولا : حساب صدق الاتساق الداخلي "لتجانس الداخلى" لمقياس مهارات

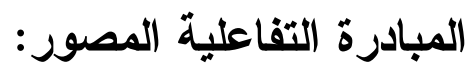

تم حساب الصدق للمقياس، بحساب معامل الارتباط بين درجـات كـلـ مهارة فرعية من المهار ات الرئيسة للمقياس مع الدرجــة الكليــة لكـلـل مهـــارة رئيسة؛ وذلك كما يوضحه جدول (r) :

r.r. العدد الثانى : أكتوبر rrr 
جلول (r)

معاملات الارتباط بين درجة كل عبارة من عبارات مقياس مهارات المبادرة

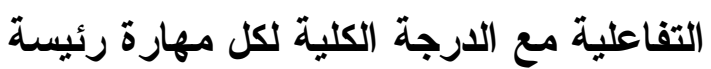

\begin{tabular}{|c|c|c|c|c|c|c|c|}
\hline مستوى الدلالة & معامل الارتباط & رقم & الرئيسارة & مستوى الدلالة & معامل الارتباط & رقم & المرئيسارة \\
\hline & **, • & $r$. & & & **, *, & 1 & \\
\hline & $* *, \nearrow, r$ & r) & & & $* *, \vee \wedge \wedge \wedge$ & r & التو اصل \\
\hline & $* *, 101$ & Yr & آداب & & $* *$, , т 9 & r & والتفاعل \\
\hline & **., 794 & r & الحوار & & $* *, 7 r q$ & $\varepsilon$ & الاجتماعى \\
\hline & $* *, T V T$ & $r \varepsilon$ & & & $* *, 900$ & 0 & \\
\hline & $* *, \nearrow \backslash \wedge$ & ro & & & $* *_{\bullet}, \wedge \vee$ & 7 & \\
\hline$\cdot, \cdot 1$ & $* *,, V Y V$ & ry & & $\cdot, \cdot 1$ & $* *, \vee \backslash 10$ & v & \\
\hline & $* *, \wedge 79$ & $r V$ & الاعتماد & & **, • ד ד & $\wedge$ & النظافة \\
\hline & $* *, \wedge \leq \varepsilon$ & rᄉ & على الأات & & $* *, \wedge \vee \wedge$ & 9 & \\
\hline & **, & rq & & & $* *, 9 \ldots$ & 1. & \\
\hline & $* *, \wedge)$. & r. & آداب & & $* *, 09 r$ & 11 & الالتز ام \\
\hline & $* *, \vee>10$ & ו & اللعب & & $* *, \vee \vee q$. & IT & بالقو اعد \\
\hline & $* *, \vee \vee 99$ & r & & & $* * ., 919$ & M & و التعليمات \\
\hline & **, & س & & & $* *, q, r$ & $1 \varepsilon$ & \\
\hline & & & & & $* *,, \vee \backslash 0$ & 10 & \\
\hline & & & & & $* *, \wedge \backslash \wedge$ & 17 & المحافظة على \\
\hline & & & & & $* *,, T \leq r$ & iv & الممتلكات \\
\hline & & & & & $* *$, Tr T & 11 & \\
\hline & & & & & **, • Тイ & 19 & \\
\hline
\end{tabular}

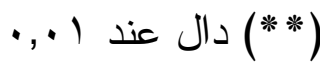

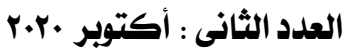

TrE

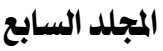


من خلال النتائج التي أسفرت عنها معاملات الارنباط، يتضح أن جميـع

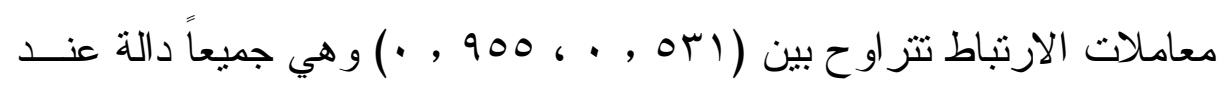

مستوي 1 ، وبالتالي فإن مفردات المقياس تتجه لقياس درجة كل مهارة من المهار ات الرئيسة لمقياس المبادرة التفاعلية .

ولتحديد مدي إتساق المهار ات الرئيسة، و الدرجة الكلية لمقياس المبــادرة

التفاعلية، تم حساب معاملات الارتباط بين درجة كل مهارة رئيـسـة، و الدرجــة

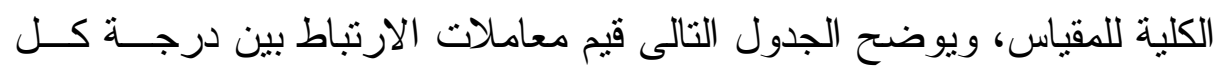
مهارة رئيسه، و الدرجة الكلية لمقياس المبادرة التفاعلية :

\section{جدول (0)}

معاملات الارتباط بين الدرجة الكلية لكل مهارة والارجة الكلية للمقياس

\begin{tabular}{|c|c|c|}
\hline | مستوى الدلالة & معامل الارتباط بالنسبة & المهارات الرئيسة بمقياس \\
\hline$\cdot, \cdot 1$ & 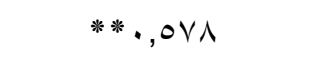 & التواصل والتفاعل الاجتماعى \\
\hline$\cdot, \cdot 1$ & $* *_{*}, \leq 77$ & النظافة \\
\hline$\cdot, \cdot 1$ & $* *^{*}, \leq 70$ & الالتزام بالقو اعد والتعليمات \\
\hline$\cdot, \cdot$, & $* *, \wedge) \vee$ & المحافظة على الممتلكات \\
\hline$\cdot, \cdot 1$ & $* *, \vee \vee Y Y$ & آداب الحوار \\
\hline$\cdot, \cdot$, & $* *, V \cdot r$ & الاعتماد على الذات \\
\hline$\cdot, \cdot 1$ & $* *, \quad 7 \leq \Lambda$ & آداب اللعب \\
\hline
\end{tabular}

r.r. العدد الثانى : أكتوبر 


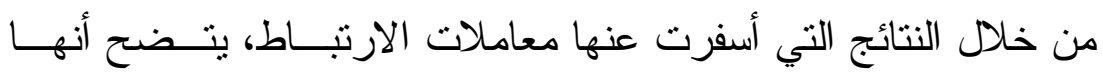

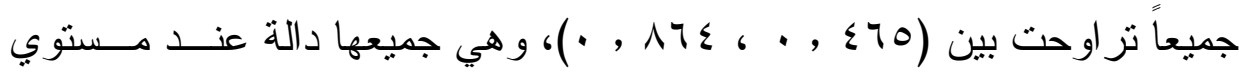
1 . , . ، وبذللك يكون المقياس مُناسباً للنطبيق علي مجموعة البحث الأساسية .

ثانيا : حساب الثبات لمقياس المبادرة التفاعلية: r يُقصد بثبات المقياس أن يُعطي المقياس نفس النتائج تقريباً إذا ما أعيــــ تطبيقه أكثر من مرة علي نفس الأفر اد تحت نفس الظروف، وقد تـمـ اسـتخدام طريقة ألفا كرونباخ؛ لحساب معامل الثبات مقياس المبادرة التقاعلية، وهي كمـــا :يلي

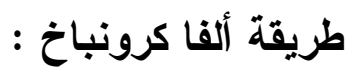

مهارة تطبيق مقيــاس المبــادرة التفاعليـــة علـــي مجموعـــة التجربـــة

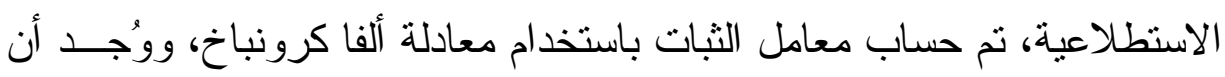
معامل الثبات للمقياس ككل كما يحددها تطبيق المعادلة علي النحو الذي يوضحه

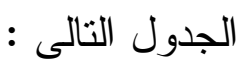

جدول (r) ( - (ب)

معامل ثبات (ألفا كرونباخ) لمقياس المبادرة التفاعلية

\begin{tabular}{|c|c|c|c|c|c|}
\hline ألفا كرونباخ & التباين & الإحراف & المتوسط & العدد & لمهارات الرئيسة بمقياس \\
\hline$\cdot, \wedge \wedge q$ & $\mid \wedge \varepsilon, V \varepsilon$ & $1 r, 0 q$ & Vr,o. & $r r$ & المقياس ككل \\
\hline
\end{tabular}

العدد الثانى : أكتوبر .r.r 
يتضح من الجدول السابق أن قيمة معامل الثبات لأبعاد المقياس كما أسفر

عنها تطبيق معادلة( ألفا كرونباخ) تر اوحت فيما بين (V) المقياس ككل فقد بلغت (1^9 , • • ) وهي قيمة مرتفعة، و هذا يُعد ثبات المقيــاس قبد البحث .

1-حساب درجة واقعية عبارات مقياس مهارات الاعتماد على الأات:

تُحدد درجة الو اقعية للعبار ات بمدي تطابق الموقف المثير مــع الموقـف

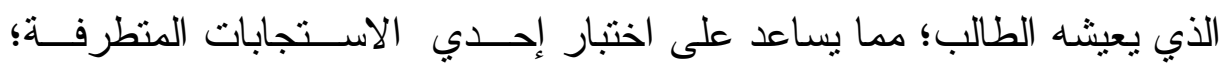
فيشير إلــي التعبيــر عـن صــدق الإتجـــاه، وتـستخدم معادلـــة هوفـستاتر Hofastaetter

مدي و اقعية العبارة = (((مج س+) + (مج س-)) / (مج س •)) (كمال

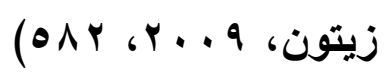

$$
\text { (مج س+) = مجموع استجابات مو افق }
$$$$
\text { (مج س-) = مجموع استجابات غير مو افق }
$$$$
\text { (مج س • ) = مجموع استجابات غير متأكد }
$$

وقد جاءت درجة الو اقعية لجميع عبار ات المقياس أكبر من الواحد مدــــا

$$
\text { يشير إلي و اقعية العبار ات و الجدول التالي يوضتح ذلك : }
$$

العدد الثانى : أكتوبر •r.r 
جدول (0)

درجة الواقعية لكل عبارة بمقياس المبادرة التفاعلية

\begin{tabular}{|c|c|c|c|c|c|}
\hline 0 & $\varepsilon$ & $r$ & $r$ & 1 & العبارة \\
\hline Trtr & 19 & 9 & 9 & 1 1، & درجة الو اقعية \\
\hline 1. & 9 & $\wedge$ & v & 7 & العبارة \\
\hline r & $\varepsilon$ & $0.7 \mathrm{~V}$ & $1,0$. & 19 & درجة الو اقعية \\
\hline 10 & $1 \varepsilon$ & ir & ir & 11 & العبارة \\
\hline $0.7 \mathrm{~V}$ & $\varepsilon$ & $0.7 \mathrm{~V}$ & $1,0$. & 19 & درجة الو اقعية \\
\hline$r$. & 19 & 11 & iv & 17 & العبارة \\
\hline$\varepsilon$ & 1617 & $0.7 \mathrm{~V}$ & 1614 & $\varepsilon$ & درجة الو اقعية \\
\hline ro & $r \leq$ & r & rr & YI & العبارة \\
\hline Trtr & r & $\varepsilon$ & $0.7 \mathrm{~V}$ & 1.0. & درجة الو اقعية \\
\hline$r$. & rq & rA & rv & ד & العبارة \\
\hline 9 & 19 & r & $\varepsilon$ & 19 & درجة الو اقعية \\
\hline & & r & rr & M & العبارة \\
\hline & & r.o. & r.r. & r & درجة الو اقعية \\
\hline
\end{tabular}

سادسيًا : اختيار عينة البحث

تم اختيار عينة البحث من أطفال الروضة من مدرسة روضة التمد وكفر

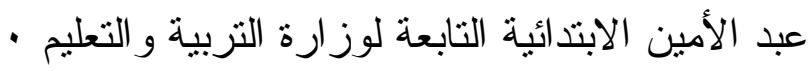


جدول (؟) وصف عينة البحث

\begin{tabular}{|c|c|c|}
\hline اسم المدرسة & عدد الأطفال & المجموعة \\
\hline روضة مدرسة التمد الابتدائية & $r$ r. & المجمو عة الضابطة \\
\hline روضة مدرسة كفر عبد الأمين الابتدائية & r. & المجموعة التجريبية \\
\hline \multicolumn{2}{|l|}{ 1 آ طقلاً } & المجموع الكلي \\
\hline
\end{tabular}

سابعًا : تم تطبيق مقياس مهـار ات المبــادرة التفاعليــة قبليًا علــى أطفــال

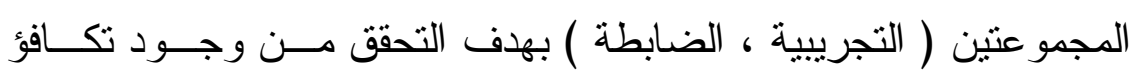

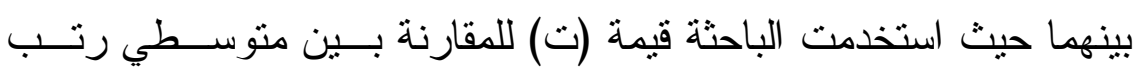
درجات مجمو عتي البحث على المقياس.

جدول (v)

جدول (9 ) : قيمة "ت" ودلاتها الإحصائية للفروق بين متوسطي درجات كل من المجموعتين (التجريبية و الضابطة) في مهارات مقياس المبادرة التفاعلية و الارجة الكلية قبلياً

\begin{tabular}{|c|c|c|c|c|c|c|c|c|}
\hline مستوى الالالة & الدلالة & " قيم " ق & الحرية & الالمعراف & المتوسط & العدد & مجموعتا & الرئيسة \\
\hline لر دالة & \&. & $\cdot, \wedge \leq 0$ & $0 \wedge$ & $\varepsilon, 99$ & $\varepsilon, \nabla \vee$ & $r$. & ييية & المقياس \\
\hline & & & & $r, v q$ & $r q, \wedge$. & $\mu$. & ضابطة & ككل \\
\hline
\end{tabular}

يتضح من الجدول السابق عدم وجود فروق ذو دلالة إحصائية بين

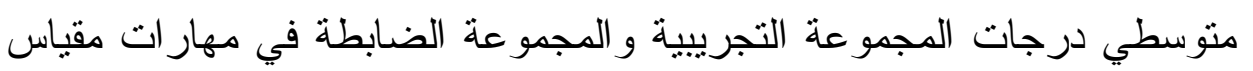

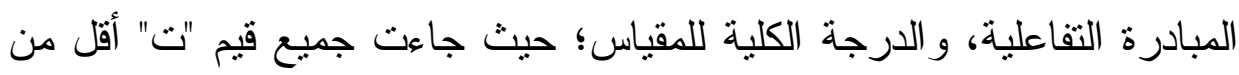

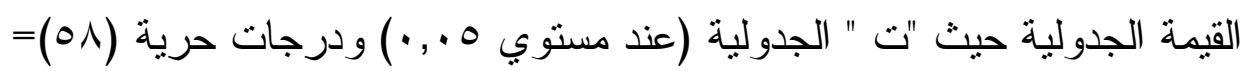
(1,91 (1) مما يدل علي تكافؤ المجموعتين في مقياس المبادرة التفاعلية القبلى. 
ثامنًا : تطبيق البرنامج المقترح

تم تطبيق البرنامج القائم على إستراتيجية اللعب التمثيلى بهدف تتمية

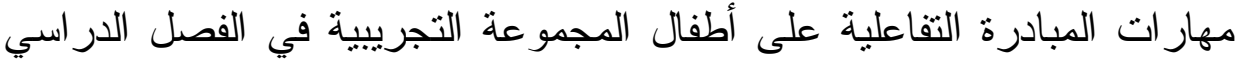
الأول بينما طبق على أطفال المجموعة الضابطة البرنامج المعد من قبل وزارة

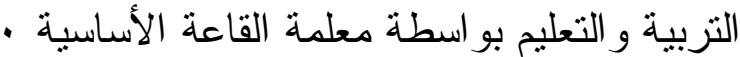
تاسعًا : التطبيق البعدي لمقياس مهارات المبادرة التفاعلية بعد الانتهاء من تطبيق البرنامج تم إعادة تطبيق مقياس مهار ات المبادرة التفاعلية بعديًا على الأطفال عينة البحث ( المجموعة التجريبية ، المجموعة

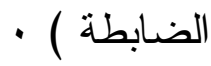
عاشرًا : المعالجة الإحصائية للبيانات .

IBM م استخدام برنامج حزم التحليل الإحصائي للعلوم الاجتماعية : SPS Statistics ver.21 ا - معادلة بيرسون لحساب الصدق" التجانس الداخلى" لأداة البحث . r- معادلة ألفا كرونباخ لحساب الثبات لأداة البحث . r- معادلة " ت" لمجموعتين غير مرتبطنين؛ لبحث دلالة الفروق بين متوسطي درجات كل من المجموعة التجريبية و المجموعة الضابطة لأداة

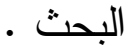
ع- معادلة "ت" للمجموعات المرتبطة لبحث دلالة الفروق بين متوسطي درجات كل من التطبيقين (القبلي و البعدي) للمجموعة التجريبية لأداة البحث . (البث. 


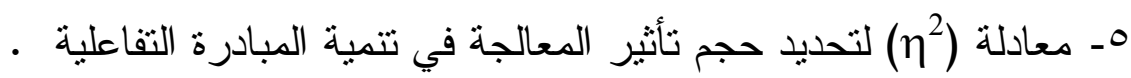

نتائج البحث ومناقشتها وتفسيرها

أولا : عرض النتائج الخاصة بمقياس مهارات المبادرة التفاعلية المصور:

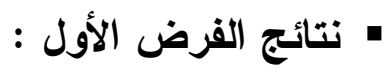

" توجد فروق ذو دلالة إحصائية عند مستوي دلالة ه.,. ب بين متوسطي درجات أطفال المجموعتين (التجريبية والضابطة) في التطبيق البعدي لمقياس المبادرة التفاعلية لصالح المجموعة التجريبية " .

استخدمت الباحثة معادلة " ت" لمجمو عتين غير مرتبطتين؛ لبحث دلالـــة الفروق بين منتوسطي درجات كل من المجموعتين (التجريبية و الــضابطة) فــي المهار ات المتضمنة بمقياس المبادرة التفاعلية و الدرجة الكلية بعدياً، و الجــدول التالى يوضتح تلاك النتائج :

(^)

قيمة "ت" ودلالتها الإحصائية للفروق بين متوسطي درجات كل من المجموعتين (التجريبية و الضابطة) في مقياس المبادرة التفاعلية والارجة الكلية بعدياً

\begin{tabular}{|c|c|c|c|c|c|c|c|}
\hline مستوى الدلالة & قيم " ت " & الحرية & الالمعراف & المتوسط & العدد & مجموعتا & الرئيسة \\
\hline دالة & $1 r, q \leq$ & $0 \wedge$ & $|1, r|$ & $v \cdot, r r$ & r. & تجريبية & المقياس \\
\hline & & & $r, 1 r$ & $\varepsilon, \nu$. & $r$. & ضابطة & ككل \\
\hline
\end{tabular}

يتضح من الجدول السابق وجود فروق ذو دلالة إحصائية بين متوســطي درجات المجمو عتين التجريبية و الضابطة) فـي الأبعــاد المت ضمنة بالمقيــاس و الدرجة الكلية للمقياس؛ حيث جاءت جميع " ت" أكبر من القيمة الجدولية حيــث

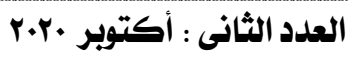
rrI 


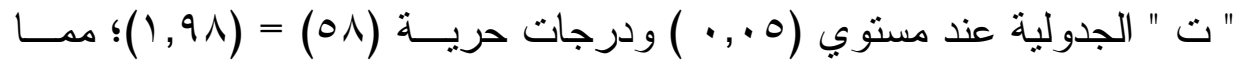

يدل علي تفوق المجموعة التجريبية علي المجموعة الضابطة في مقياس المبادرة التفاعلية ؛ مما بدل فعالية المعالجة التجريبية من أثر في تتمية أبعـاد المبــادرة - التفاعلية

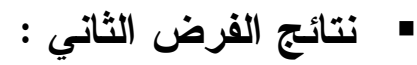

توجد فروق ذو دلاحة إحصائية بين متوسطي درجات أطفال المجموعة التجريبية في التطبيقين (القبلي والبعدي) لمقياس المبادرة التفاعلية لصالح

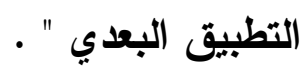

استخدمت الباحثة معادلة "ت" للمجموعات المرتبطة لبحث دلالة الفروق بين

متوسطي درجات كل من التطبيقين (القبلي و البعدي) للمجموعة التجريبية في المهارات الرئيسة لمقياس المبادرة التفاعلية و الدرجة الكلية، و الجدول التالى يوضح تلك النتائج : جدول (9) : قيمة "ت" ودلالتها الإحصائية للفروق بين متوسطي درجات كل من التطبيقين (القبلي والبعدي) للمجموعة التجريبية في المهارات الرئيسة لمقياس المبادرة التفاعلية والارجة الكلية

\begin{tabular}{|c|c|c|c|c|c|c|c|}
\hline مستوى & قيم " ت " & ل الحرية & الاحمراف & المتوسط & العدد & القياس & المهارات الرئيسة لمقياس \\
\hline دالة & 17,17 & rq & $|1, r|$ & $v \cdot r r$ & $r$. & بعدى & المقياس \\
\hline & & & $\leqslant, 99$ & $\varepsilon \cdot, \vee V$ & $r$. & قبلى & ككل \\
\hline
\end{tabular}

يتضح من الجدول السابق وجود فروق ذو دلالة إحصائية بين متوسطي درجات التطبيقين (القبلي و البعدي) في المجموعة التجريبية في المهارات

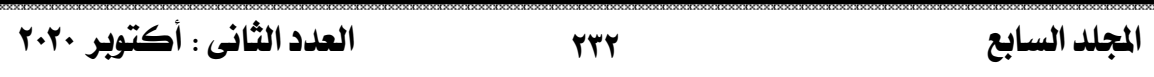


الرئيسة لمقياس المبادرة التفاعلية و الدرجة الكلية للمقياس؛ حيث جاءت جميع قيم "ت " أكبر من القيمة الجدولية حيث "ت" الجدولية عند مستوي(0 • , •) ودرجات حرية (Yq) = (Y) (Y) ) مما يعني حدوث نمو في مقياس المبادرة التفاعلية بمهار اته الرئيسة لدي المجموعة التجريبية؛ مما يدل علي فعالية المعالجة التجريبية في تتمية مهار ات المبادرة التقاعلية .

\section{" فعالية المعالجة التجريبية في تنمية مهارات المبادرة التفاعلية}

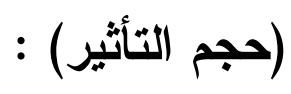

لتحديد فعالية المعالجة التجريبية في تتمية المبادرة التفاعلية؛ قامت الباحثة باستخدام معادلة (ך) لتحديد حجم تأثنير المعالجة في تتمية كل مهارة رئيسة من المهار ات المتضمنة بمقياس المبادرة التفاعلية، وكذلك الدرجة الكلية اعتماداً علي قيمة "ت" المحسوبة عند تحديد دلالة الفروق بين التطبيقين (القبلي و البعدي) للمجمو عة التجريبية، و الجدول التالى يوضح ذلك :

$$
\text { جدول(r) }
$$

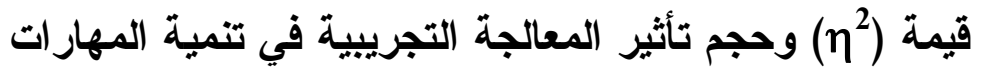

\begin{tabular}{|c|c|c|c|}
\hline حجم التأثير & $\eta^{2}$ & قيم " ت " & المهارات الرئيسة \\
\hline كبير & ד & 14,17 & المقياس ككل \\
\hline
\end{tabular}

الرئيسة لمقياس المبادرة التفاعلية و الارجة الكلية

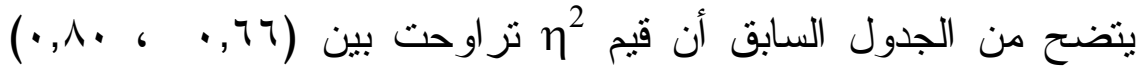

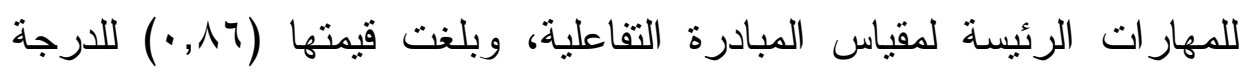
الكلية؛ مما يعني أن المعالجة التجريبية تسهم في التباين الحادث في المهار ات اترة

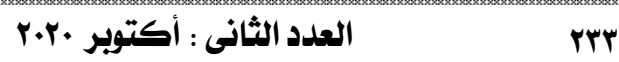

المجلد السابع 
الرئيسة لمقياس المبادرة التفاعلية بنسبة 1>1\%، مما يدل علي فعالية المعالجة التجريبية في تتمية المهار ات الرئيسة لمقياس المبادرة التفاعلية لدي المجموعة

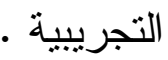

ثانيا : مناقشة التتائج الخاصة بمقياس مهار ات المبادرة التفاعلية المصور وتفسيزها :

يتضح مما سبق أن استخدام اللعب التمثيلى مع طفل الروضة من ابرز الطرق و الاستر اتيجيات التدريسية المناسبة لتعلم طفل الروضة ، فمن خلالها يصبح للطفل دور إيجابى يتميز بكونه عنصر نشط وفعال داخل القاعة لما يتسم به هذا الأسلوب التدريسى من التفاعل بين المعلم و المتعلمين من خلال لعب

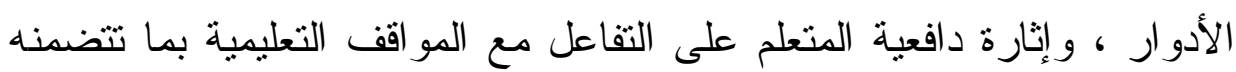
من مواد تعليمية جيدة وأنشطة تربوية هادفة ، فاللعب التمثيلى يساعد الطفل على أن يدرك العالم الذى يعيش فيه، ومن خلال اللعب التمثيلى يتعرف الطفل على الأشكال والألوان والحروف والأعداد ، ويقف على ما بميز الأشياء المحيطة به من خصائص وما يجمع بينهما من علاقات ، أيضا يتعلم الطفل من خلا اللعب التمثيلى بعض المفاهيم و المهار ات المرغوبة التى يجب على الطفل أن يتعلمها مثل الوعى بالمهار ات الاجتماعية ويتفق هذا مع نتائج دراسة (امل القداح ، . . † )و التى استخدمت فاعلية برنامج مقتر ح لتتمية بعض المهار ات الاجتماعية مثل ( المبادرة التفاعلية ، آداب الاستئذان ، الاحتر ام ، التو اصل ، تحمل المسئولية ، التعاون ) لدى أطفال الرياض من خلال المواقف الحياتية ، ودر اسة (coper,smith \&smith , 2000) و التى استخدمت برنامج لتحسين المهار ات الاجتماعية لاى مجموعة من أطفال الروضة ، ودر اسة (نادية التيه ، وليه

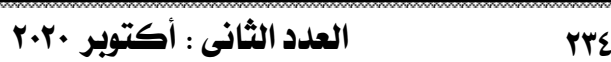

المجلد السابع 


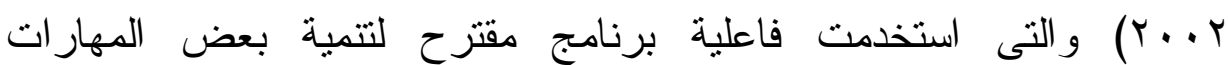
الاجتماعية و أسلوب حل المشكلات على السلوك النو افقى لطفل ما قبل المدرسة

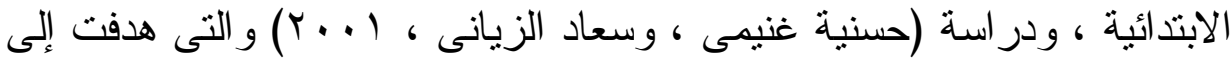

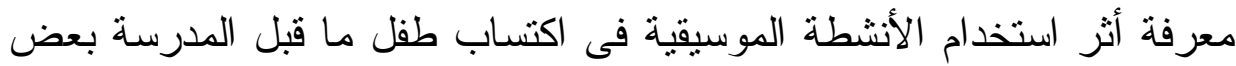

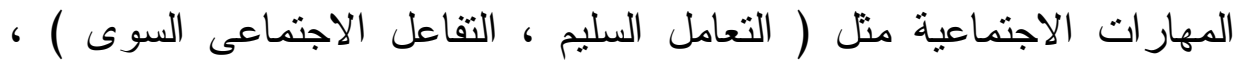

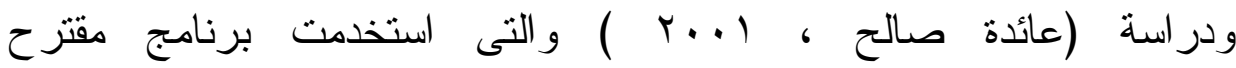

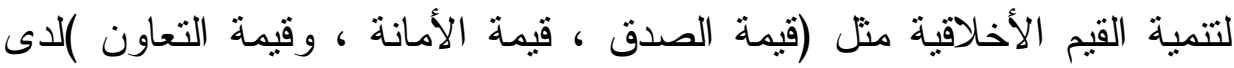

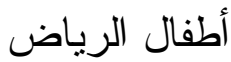

فمن خلال ما أظهرته النتائج من فعالية استخدام اللعب التمثيلى فى تنمية المبادرة التفاعلية لدى طفل الروضة يمكن أن ترجع النتائج إلى عدة

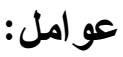

1. إن استخدام استر اتيجية اللعب التمثيلى أدى إلى تتميــة أبعـاد المبــادرة التفاعلية لدى طفل الروضة من خلال جعل الطفل هو محسـور العمليــة التعليمية. r. إن استخدام موضو عات تمس حياة طفل الروضة قلـلـ مـن صــوبتها

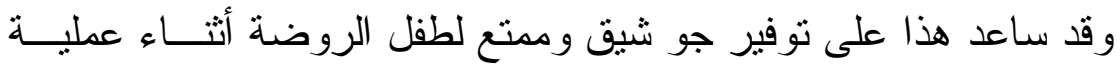

$$
\text { التعلم. }
$$

r. كما ساعدت استر اتيجية اللعب التمثيلى على تبسيط المعلومة لاى الطفل

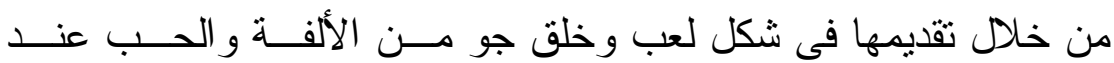

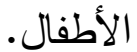

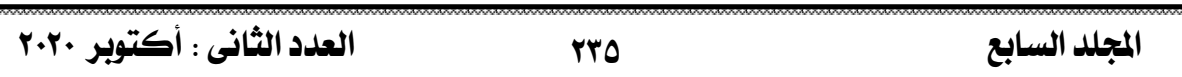


ء. أسهمت استز اتيجية اللعب التمثيلى فى التفاعل الإيجابى بــين الأطفــال

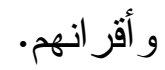

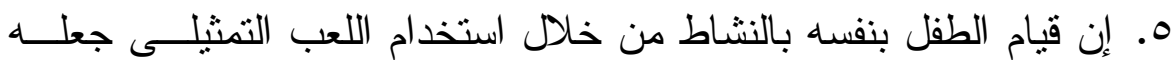

$$
\text { مستمتعا محبا للنشاط. }
$$

7 ا إن وضع المبادرة التفاعلية فى قالب لعب يساعد الأطفال فــى اكتـساب

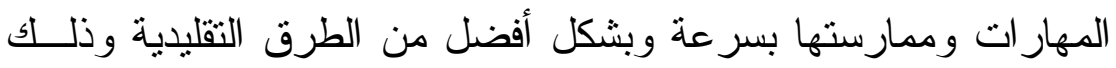

$$
\text { لر غبة الطفل بالقيام باللعب. }
$$

V. جذب انتباه الأطفال وزيادة دافعيتهم للتعلم من خــلال اســتخدام اللعــب

$$
\text { التمثيلى }
$$

^. ما قدمه البحث من مهار ات للأطفال ساعد فى زيادة المبادرة التفاعليــة

$$
\text { لديهم. }
$$

ومن خلال ما سبق يمكن التأكيد على أن اللعب التمثيلى له بصمة فـى

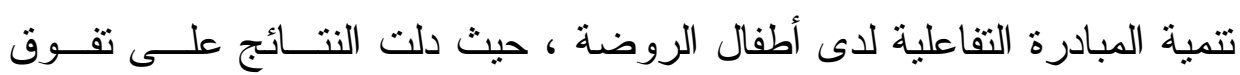

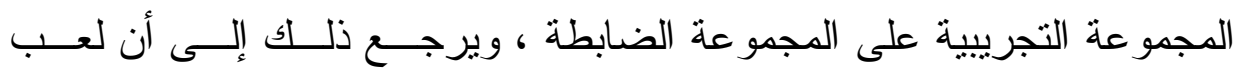
الأدوار من أكثز الوسائل التى تشد انتباه الأطفال كمــا تـسـاعد علــى تزكيـز

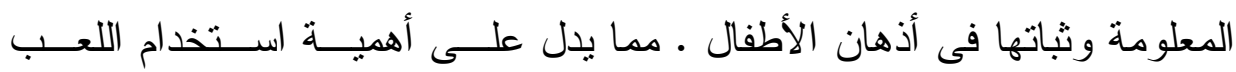
التمثيلى مع أطفال الروضة . 


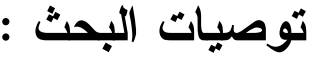

1- تتفيذ برنامج للعب الأدوار على عينات أكبــر مــن أطفــال الروضـــة

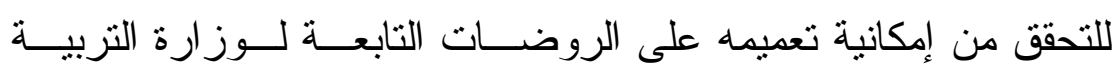

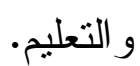

r- الاهتمام بعمل دور ات تدريبية للمعلمات فى مدارس الروضات لتدرييهم على مو اكبة كل ما هو جديد فى أساليب و استراتيجيات تعليم هذه الفئسة

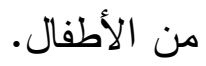

ب- توفير أنشطة اللعب التثثيلى و الوسائل التعليمية و الأنـشطة الاجتماعيــة التى يمكن أن تسهم بدور فعال فى تتمية المبادرة التفاعلية.

ع- توعية الو الدين بضرورة التعاون الإيجابى المثمر فى العملية التعليميــة

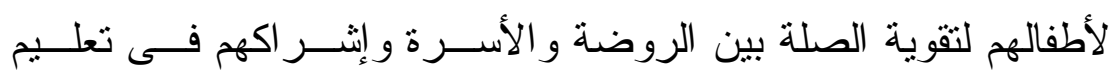
الأطفال ، لما فى ذلك من أهمية كبيرة فى توجيه وتعديل سلوك الأطفال

$$
\text { فى هذه المرحلة. }
$$

0- ضرورة وجود علاقة حب وود مثبادلة بين المعلمة و أطفال الروضــة ،

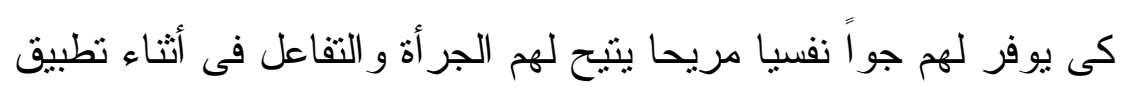

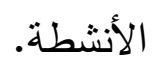

؟- تزويد أطفال الروضة بالأدوات الخاصة لكل مــنهم ، لتتفـــــ الأنـشطة و إتاحة الفرصة لهم لتتفيذها بأنفسهم.

العدد الثانى : أكتوبر ·r.r. 


\section{بحوث و دراسات مقترحة :}

ا- إجر اء در اسة مماتلة على الأطفال من الفئات الأخرى باستخدام اللعـب

$$
\text { التمثيلى. }
$$

r- وضع تصور مقتر ح للبر امج التدريبية اللازمة لإعداد معلمــات أطفــال

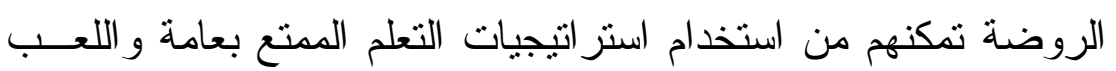

$$
\text { التمنيلى بخاصة. }
$$

r- در اسة أثز استخدام استر انتيجية اللعب التمثيلى على متغير ات أخرى منل

$$
\text { مهار ات المشاركة المجتمعية. }
$$

ع- استخدام برنامج قائم على اللعب التمثيلى فى علاج صعوبات المهـار ات

$$
\text { الاجتماعية للفئات العادية . }
$$

0- استخدام استر اتيجية اللعب التمثيلى فى تتمية المهار ات الحياتيــة لــدى

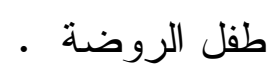

\section{المر اجع}

\section{أولاًا : المراجع العريية}

1- أسامة فارق مصطفي سالم(10 ـ ؟؟): اضطر ابات التواصل بين النظريــة

$$
\text { والتطبيق، دار المسيرة، عمان، الأردن. }
$$

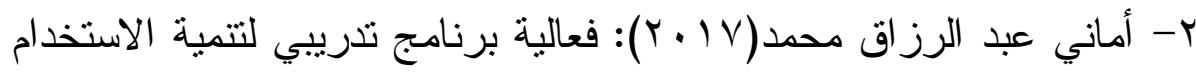

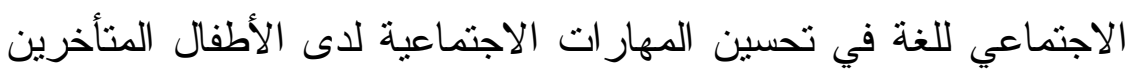

لغويا، رسالة ماجستير غير منشورة، كلية التزبية، جامعة الزقازيق.

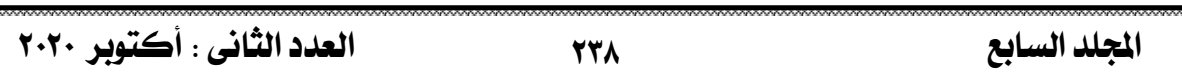




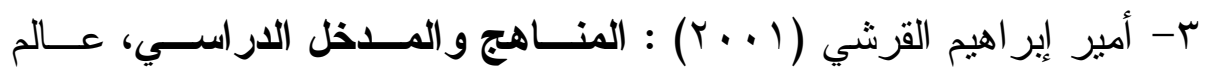

$$
\text { الكتب، القاهرة. }
$$

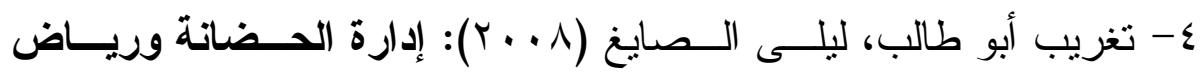

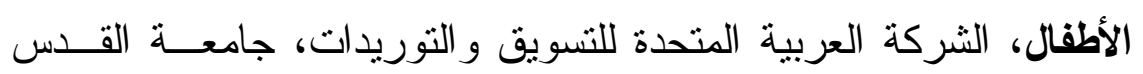

$$
\text { المفتوحة. }
$$

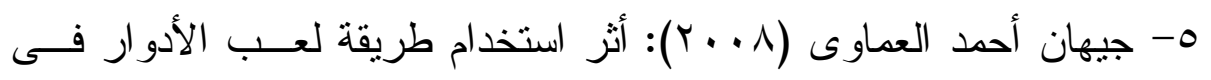

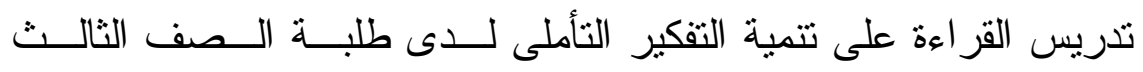
الأساسى، رسالة ماجستير غيــر منـشورة، كليـــة التربيــة، الجامعـــة الإسلامية، غزة.

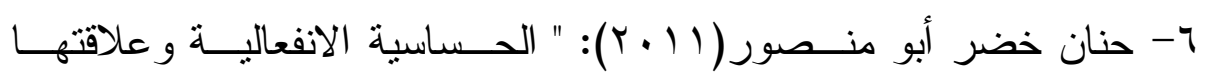
بالمهار ات الاجتماعية لدي المعاقين سمعياً في محافظات غزة " ، ، رسـالة ماجستير ، الجامعة الإسلامية، غزة.

V- حنان عبد الحميد العناني (V . . . Y): الاراما والمسرح في تربية الطقـل، دار الفكر، عمان، الأردن.

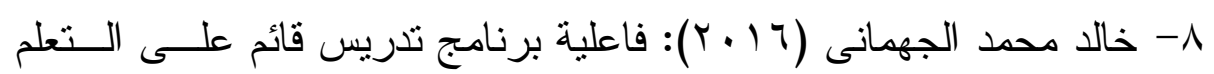
عن طريق لعب الأدوار فى تحسين الاستيعاب القر ائى لاى تلاميذ الصف الثالث الأساسى وتتمية اتجاهاتهم نحو القراءة ، رسـالة دكتــور اه غيــر منشورة، كلية التزبية ، جامعة دمشق • 9- دخيل بن عبد الله الدخيل الله (ع ا ـ ب): المهـــارات الاجتماعيــة تـــريب وتمارين ومناهج وتقييم، جامعة الملك سعود، العبيكان، المملكة العربيــة السعودية. 


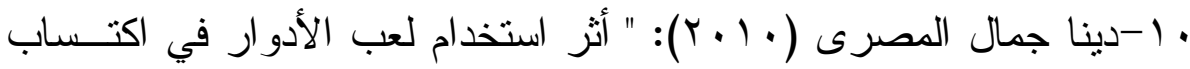

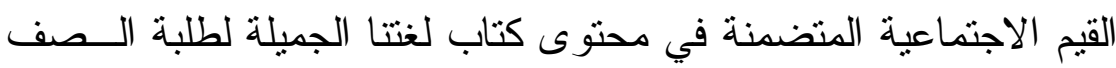

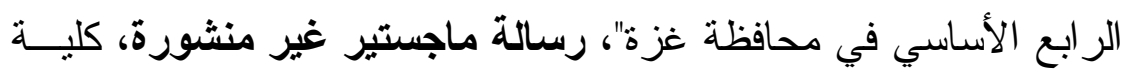
التزبية، الجامعة الإسلامية، غزة .

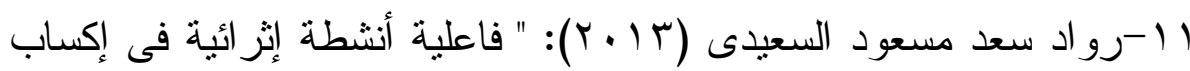

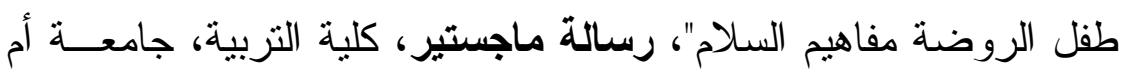
القرى، المملكة العربية السعودية .

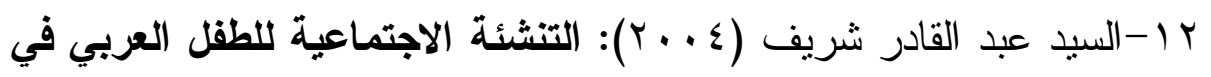
عصر العولمة، دار الفكر العربي، ط (؟)، القاهرة.

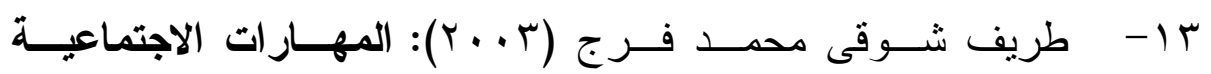
والإتصالية، دار غريب، القاهرة.

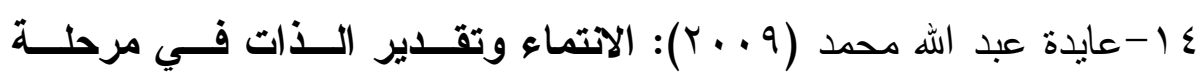
الطفولة، دار الفكر : عمان، الأردن.

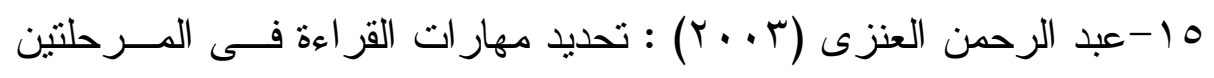

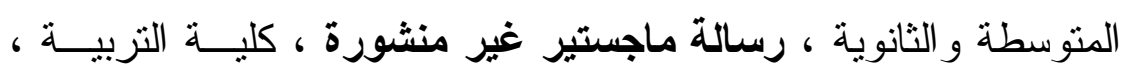
جامعة الملك سعود ، الرياض ، السعودية .

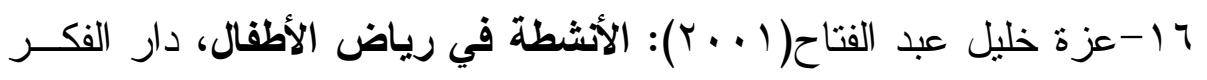
العربي، الطبعة الثانية، القاهرة.

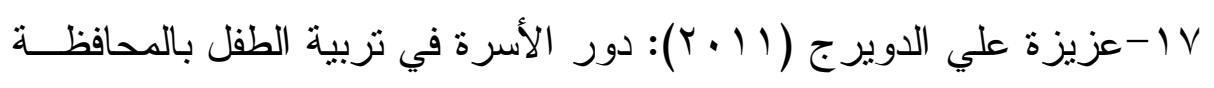

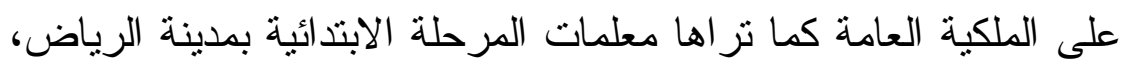


رسالة ماجستير غير منشورة، كلية العلوم الاجتماعية، جامعسـة الإمــام

$$
\text { محمد بن سعود الإسلامية، المملكة العربية السعودية. }
$$

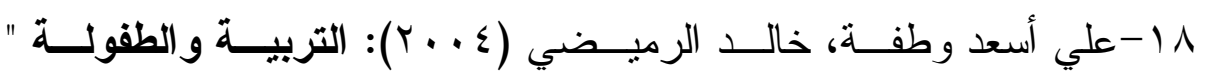
تصورات علمية وعقائد نقدية" ، الطبعة الأولى، مجد المؤسسة الجامعية لللار اسات و النشر و التوزيع، الأردن.

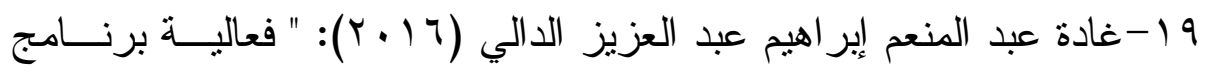
تدريبي لتتمية الوعي الفونولوجي و أثره على بعض المهار ات الاجتماعية

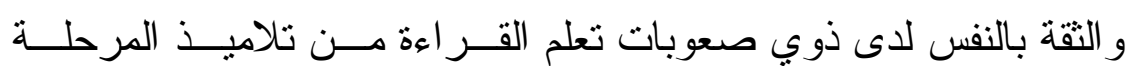

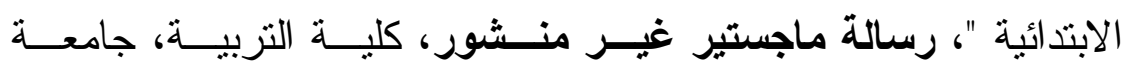

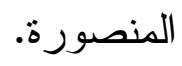

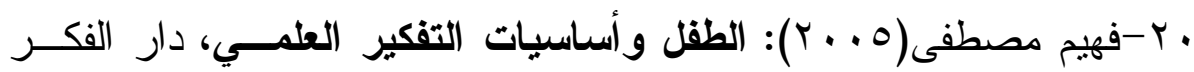

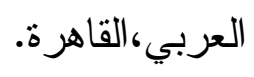

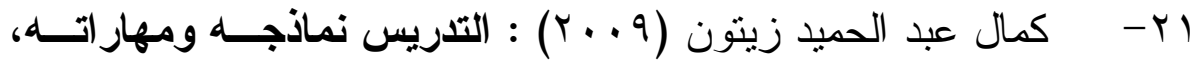

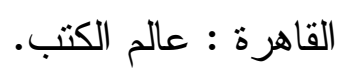

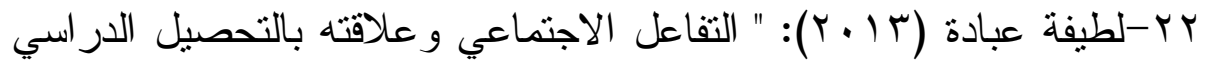

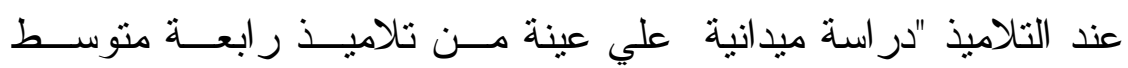
بمتوسطة الثيخ الدقراني "، رسالة ماجستير غير منشورة ، كلية العلوم الاجتماعية و الإنسانية، جامعة الو ادي، سوريا.

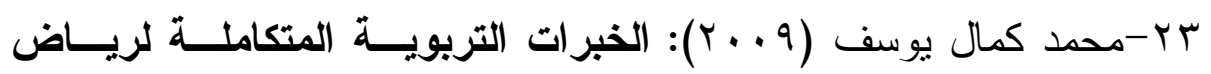
الأطفال، دار النشر للجامعات، القاهرة. 


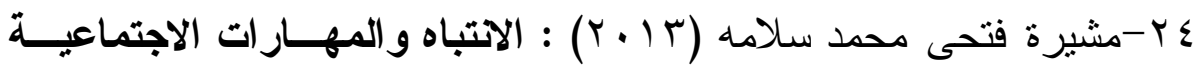

لاى الأطفال الأتويين ، مؤسسة طيبة للنشر و التوزيع ، القاهرة .

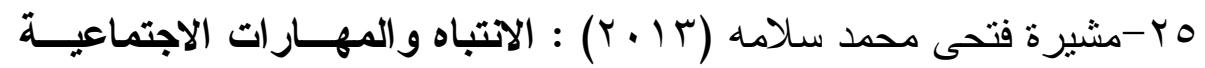
لاى الأطفال الأتويين ، مؤسسة طيبة للنشر و التوزيع ، القاهرة .

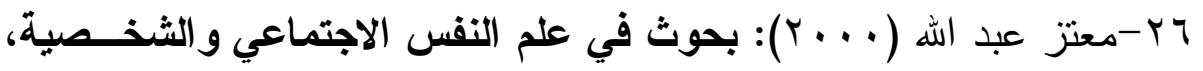
دار غريب للطباعة و النشر و التوزيع، القاهرة.

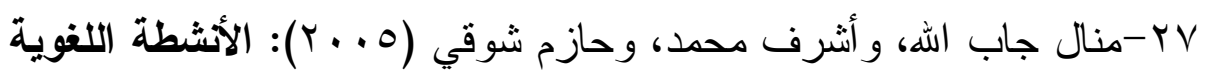
أنواعها معاييرها استخد/ماتها، دار الكتاب الجامعي، العين، الإمــار ات العربية المتحدة.

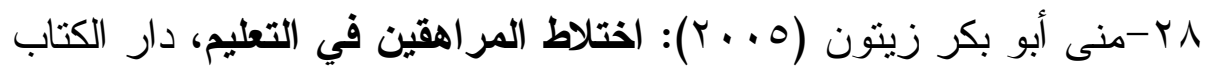
الجامعي، العين، الإمار ات العربية المتحدة.

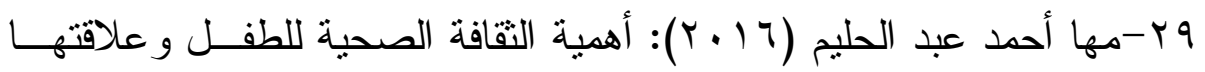
بصحة الأم و المجتمع من وجهة نظر معلمات رياض الأطفــال بمحليــة

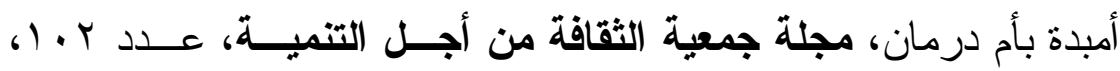
السودان.

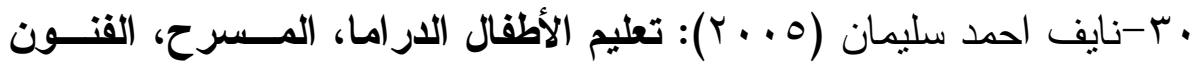
التشكيلية، الموسيقى، دار صفاء للنشر، عمان، الأردن. اب-نبيل أحمد عبد الهادي (ع . . ץ): نماذج تربية تعليميــة معاصــرة، دار

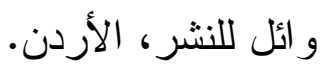




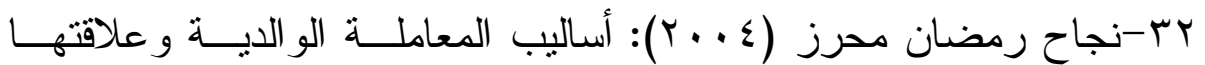

بتو افق الطفل الاجتماعي و الثخصي في رياض الأطفال، مجلة جامعــة

$$
\text { دمشق، مج( Y ()، ع ( ( )، كلية التربية جامعة دمشق، سوريا }
$$

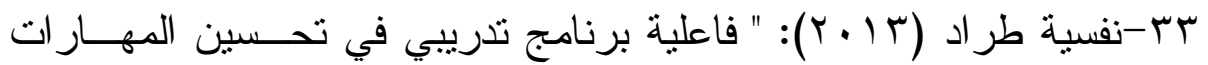

الاجتماعية لدى عينة من الأطفال التوحديين " در اسة ميدانية علي عينــة

من الأطفال التوحديين بالمركز الطبي التربوي للمتخلفين ذهنياً بتقرت "،

رسالة ماجستير غير منشورة ، كلية العلــوم الإنـسانية و الاجتماعيــة،

جامعة قاصدي مرباح ورقلة، الجز ائر •

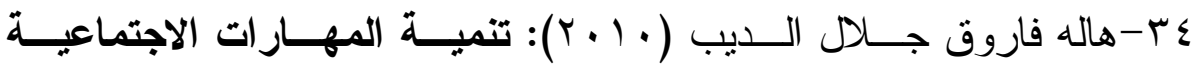

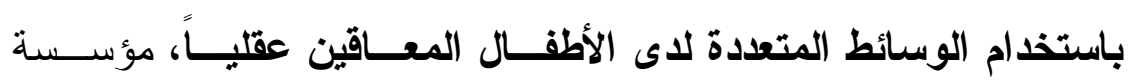

$$
\text { ثانيًا : المراجع الأجنبية الدولية، الإسكندرية. }
$$

35-Erturk. E, (2015): Role Play as a Teaching Strategy, National Tertiary Learning and Teaching Conference, Tauranga .

36-Mucha.J. (2003) : The concept of Social relations in Classic Analytical Interpretative Sociology, 6th ESA Conference MURCIA . 
37-Brodeski. J, Hembrough. M. (2007)： IMPROVING SOCIAL SKILLS IN YOUNG CHILDREN, Master Thesis, Saint Xavier University Chicago, Illinois .

38-Lin. C. Y (2020) : Social reaction toward the 2019 novel coronavirus (COVID-19), Social Health and Behavior Journal, Vol.(3), No. (1), PP.(1-4).

39-Thomas.P. A, Liu. H \& Umberson. D. (2017) : Family Relationships and Well-Being, Innovation in Aging Journal, Vol. (1), No. (3), PP.(1-11). 